\title{
Are Managers 'Under-the-Weather' During Earnings Conference Calls?
}

This Draft: August 2018

\begin{abstract}
Earnings conference calls represent an important communication channel between managers and investors. We examine the impact of weather-induced mood on manager behavior during these calls. Using a large sample of earnings conference calls from 2006 to 2017, we find managers speak more negatively and with less (more) quantitative information (uncertainty) when local weather conditions are bad. We further identify that this negative relation is less pronounced for CFOs than CEOs. Financial expertise mitigates negative behavior bias induced by weather and we confirm with subgroups of CEOs with previous financial experience. We document a significantly negatively market reaction to weather-induced behavior that cannot be explained by existing textual analysis methods. Our results remain significant after adding controls for investor mood, separating firms into those from big and small states, mediation tests, firm fixed effects, and propensity score matching. Taken together, our findings suggest that exogenous effects of bad weather significantly impact manager behavior that the market views negatively.
\end{abstract}

JEL Classification: G14, G41, M41

Keywords: Weather; Managerial Mood; Earnings Conference Calls; Cloud Cover 


\section{Introduction}

Mood is an essential component in determining both human behavior and economic activities. Keynes (1936) investigates firm level investments under economic uncertainty, and finds mood is the reason why investment diverges from optimal levels. In more recent work, Akerlof and Shiller (2009) attribute recessions to negative sentiment from individuals. Previous research in finance and economics also demonstrates that decisions made by important economic actors are influenced by emotion (e.g. Saunders, 1993; Hirshleifer and Shumway, 2003; Goetzmann et.al., 2014; deHann, Masden, and Piotrowski, 2017). For instance, deHann et.al. (2017) show that the mood of equity analysts affects the speed of response to an earnings announcement. We follow this stream of literature by looking at an important economic actor in firm decisions- top executives. In particular, we suggest that managerial mood will influence executives' behavior such as the language used during earnings conference calls. The literature on managerial mood suggests that managerial decisions are highly influenced by emotions such as being overly optimistic or pessimistic. For example, Antoniou et al. (2017) find pessimistic managers who are influenced by extreme negative event temporarily reduce $R \& D$ expenditures, reduce long-term leverage, and increase cash holdings.

Despite the potential role that managerial mood plays in the decision making, it is difficult to measure managerial mood directly since it is unobservable. To address this difficulty, existing research implies that local sunshine level has a significant impact on an individual's mood but is also orthogonal to the economic environment (Chhaochharia et.al., 2017). Scott (2007) investigates the relationship between daily mood and daily sunshine and finds sunshine to be a crucial factor in mood adjustment. This relationship has also been analyzed in the neurobiology 
literature. Spindelegger et al. (2012) suggest that the level of serotonin, which is associated with happiness and elevated emotional states in human's mind, will vary with levels of sunlight.

Using a sample of 57,374 earnings conference call transcripts for U.S. based companies from 2006 to 2017, we seek to answer the following two questions: how does weather-induced mood change the content/tone of top executives during an earnings conference call and is any weather-induced change captured by market prices? There are several important advantages to using earnings conference calls to measure weather-induced behavioral changes. First, the time of an earnings conference call is usually set in advance which means the date must be decided at least several days before the meeting. This presetting characteristic ensures the event date is unrelated to weather conditions. Secondly, the conference call lasts no more than one day which improves weather identification. Third, an earnings conference call typically contains a Q\&A session between managers and analysts which a manager cannot prepare in advance, and we can measure weather-induced behavior change in near real-time.

Following the existing literature in measuring the impact of sunshine on mood, we use seasonally-adjusted local sky coverage to construct our primary measure of weather-induced mood (Saunders 1993; Hirshleifer and Shumway, 2003; deHann, Masden, and Piotrowski, 2017). To be specific, we measure the average daytime (from 6 am to $6 \mathrm{pm}$ ) cloud cover of all weather stations within a 50 miles radius of a firm's headquarter on the earnings conference call date. Then, we further deseasonalize the weather measurement by adjusting for weekly mean cloud cover (Hirshleifer and Shumway, 2003). Finally, we separate weather into two categories- good weather and bad weather- by the level of cloud coverage.

Prior research (e.g., Antoniou et al., 2017; Chen et al.,2017b) has established that managerial mood will change an executive's perception and confidence level for the company. 
Davis et.al. (2015) concluded that earnings conference calls contain information related not only to firm's fundamental but also to manager-specific components. Zhou (2014) also mentions that a manager will choose to talk more about the external environment in the earnings conference call when firm performance is bad. Therefore, managers' negative mood could affect their behavior during an earnings conference call in at least two ways. First, negative mood may alter manager tone during the conference call by changing manager's perception of firm future performance. Second, any negative feeling will also change the confidence level of a manager by decreasing the percentage of quantitative information provided and increasing uncertainty in language used during the call.

We find that, ceteris paribus, mean net tone, measured as the percentage of positive minus negative words (Loughran and McDonald, 2011) in the Q\&A section, is lower by 5\% of the mean when weather is bad during the day of an earnings conference call. This evidence suggests that severe weather induces manager's negative perception of firm future performance which is consistent with the argument in psychology literature that individuals in a bad mood will overestimate the probability of negative events (Johnson and Tversky, 1983). To examine changes of call content, we focus on both quantitative information and uncertain language. Zhou (2017) indicates that the use of numerical content inside an earnings conference call depends on managerial confidence. As bad weather generates a more pessimistic view, we predict that the percentage of numbers used will decrease and uncertainty words will increase as a result. The result is as predicted as the use of numbers significantly decreases by around $2 \%$ from the mean when weather is bad and the use of uncertainty significant increases by $2 \%$.

For our second question, the existing literature demonstrates that the market reacts to information inside earnings conference calls (Frankel et al. 1999; Loughran and McDonald, 
2016). We predict that the market negatively reacts to pessimistic managerial mood from bad weather during the call date. The results support our prediction: controlling for net tone and quantitative information in the call, we find that bad weather decreases the market reaction (cumulative abnormal return from one day before to one day after) by $0.21 \%$ which translates into an average \$20 million market value reduction in firm market capitalization. Although fluctuations in cloud cover are likely to capture only a fraction of variation in managerial mood, this result suggests that associated mood changes play an economically material role in market reaction beyond that which is captured by textual analysis methods in the literature. This result holds when (1) controlling for investor mood; (2) examining propensity-score matched pairs; (3) controlling for clustering of our sample in some specific states. Previous research demonstrates that the tone of disclosure after an earnings announcement also influences PEAD (Feldman et al. 2010). As such, we also look at the persistence of weather effects on conference calls by examining post-earnings announcement drift (PEAD). We find that the bad weather effect is consistently associated with more negative PEAD.

To confirm net tone and numerical information are the channels between weather conditions and market reaction, we employ the Sobel test which is a widely used mediation test in the management literature (Baron and Kenny, 1986; Judd and Kenny, 1981; James and Brett,1984). The results confirm that net tone and numerical information are mediators between weather conditions and market reaction. Prior research (Keller et.al, 2005) also notes that the weather effects on mood may be asymmetrical: the effect of bad weather on mood is more pronounced than good weather on mood. We confirm these asymmetric effects in that only poor weather influences managerial tone, quantitative information, uncertainty, and returns around earnings conference calls. 
As the predictions described above do not distinguish effects on individual executive types, we conduct additional tests to examine weather effects on the Chief Executive Officer (CEO) and Chief Finance Officer (CFO) respectively. We find a significant (insignificant) relationship between the content and tone expressed by CEOs (CFOs) and bad weather. These results support Chen et al.'s (2017) argument that financial expertise plays an important role between weatherinduced mood and corporate tax avoidance decisions. Previous research (Bertrand and Schoar, 2003; Malmendier and Tate, 2005; Custodio and Metzger, 2014) uses CEOs with previous working experience in financial roles to represent financial expertise. As such, we show similar insignificant weather effects for CEOs with financial expertise for numbers and uncertainty words usage. We also examine other potentially moderating executive characteristics including tenure, gender, and age. We find that short-tenured, female, and young executives are less affected by weather-induced mood change.

This paper contributes to the literature in several important ways. First, our results improve our understanding of voluntary disclosure by identifying an additional factor, weather-induced mood, which affects information content within earnings conference calls. Consistent with previous literature on tone management (Huang et al. 2014), we show that managers not only intentionally change tone to influence investors but also inadvertently change tone due to weather-induced mood.

Second, our findings contribute to the growing literature that identifies weather as a channel through which mood affects important economic actors' activities. While the majority of work in finance has concentrated on the effects of weather on the stock market (Saunders, 1993; Hirshleifer and Shumway, 2003; Goetzmann and Zhu, 2005), recent papers (deHaan et al. 2017; Chen et al. 2017a; Chen et al., 2017b) investigate other important economic actors such as 
analysts and executives. However, none of this previous research shows a clear causal relationship between mood and economic outcomes since these prior works use weather-induced mood over long time periods. As far as we know, through the use of earnings conference calls, we are the first paper to document the direct effect of weather on managerial mood and its impact, distinct from net tone and quantitative information, on financial markets.

The rest of the paper is organized as follows. Section 2 discusses the related literature and Section 3 lists our hypotheses. Section 4 describes the sample selection and construction of our weather measurement. Section 5 shows our results. Section 6 presents robustness checks. Section 7 provides some additional analysis. Section 8 concludes.

\section{Literature Review}

Previous research in both psychology and neurobiology has studied the relationship between weather conditions and human mood. In the social psychology literature, the level of sunshine has been shown as positively related to an individual's self-reported mood (Cunningham,1979; Schwartz and Clore, 1983). Parrott and Sabini (1990) further conclude that exposure to cloud cover serves as an effective way to elicit an individual's mood. Sunshine is also an effective method to treat depression. Lam et al. (2006) argue that light therapy is an effective way to treat many types of mood disturbance and depressive disorders.

Extensive studies in neurobiology address this relationship by performing blood tests on human subjects (Lambert et al., 2002; Spindelegger et al. 2012). Studies find that sunshine exposure increases the release of serotonin, which is a monoamine neurotransmitter associated with happiness and elevated emotional states. When the amount of sunshine exposure drops, the human brain produces more of a hormone called melatonin, which is associated with depression, sleepiness, and fatigue. 
The relationship between mood and behavior is also heavily studied in social psychology (Tversky and Kahneman, 1973; Isen et al., 1978; Bower, 1981; Johnson and Tversky, 1983; Forgas and Bower, 1987). These studies demonstrate that individuals in a good mood tend to overestimate the likelihood of positive events and underestimate that of negative events, while individuals in a bad mood exhibit the opposite tendency. Carlson et al. (1988) demonstrate that bad mood causes people to retrieve negative information from memory. Peterson (2000) further provides evidence that individuals are more likely to evaluate targets pessimistically when they are in a bad mood. If we combine these two streams of literature, we can form a clear relation between weather and an individual's behavior. People in bad weather will retrieve more negative information from memory and this negative memory will make people become more pessimistic.

Consistent with previous literature, studies in finance also document weather effects in financial markets. Early studies focus on the influence of weather on stock markets (Saunders, 1993; Hirshleifer and Shumway, 2003) and argue that investors are more pessimistic during cloudy days, which leads to lower stock returns. In more recent years, research has shifted focus to other important economic actors who have been previously assumed to be rational and exhibit less behavioral bias. Cortes, Duchin, and Sosyura (2016) focus on low-level bank financial officers and find the approval rate for credit applications is higher during sunny days. They attribute this relationship to increased optimism of bank financial officers under better weather conditions. Two recent studies focus on the same group of people that we seek to analyze, top executives (Chen et al., 2017a; Chen et al., 2017b). Chen et al. (2017b) examine the relationship between weather conditions and executive tax avoidance decisions. They find that bad weather increases levels of tax avoidance. In Chen et al. (2017a), the authors investigate weather effects on managerial earnings forecasts and find that the level of sunshine around corporate 
headquarters is positively related to management forecast bias. However, this prior research uses only long-term weather measurements. ${ }^{1}$ As a result, these two studies can only provide indirect evidence of the relationship between weather conditions and executive decisions or behavior. Using earnings conference call data and a short estimation window, we offer more direct evidence of this relationship.

\section{Hypothesis Development}

Our hypotheses are built around two primary research questions: how does weather-induced mood influence managers' behavior during earnings conference calls and does the market react to weather-induced behavior changes? For measuring behavioral changes during earnings conference calls, we use three communication measures: net tone, numerical information usage, and uncertainty.

One of the most frequent measurements extracted from earnings conference calls is net tone which represents the sentiment that is expressed by call participants from the company and external analysts (Loughran and McDonald, 2011). Existing research shows that the tone of an earnings conference call is significantly influenced by manager-specific tendencies to be optimistic or pessimistic (Davis et al., 2015; Huang et al., 2014). If bad weather makes an individual become more pessimistic, then, ceteris paribus, the manager will use more negative words when speaking during an earnings conference call. Thus, we hypothesize:

H1: Bad weather is negatively correlated with net tone by managers during earnings conference calls.

\footnotetext{
${ }^{1}$ Chen et al. (2017b) use yearly weather measurement and Chen et al. (2017a) use the average daily sky cover over a 14-day window proceeding the earnings forecast announcement date.
} 
The second set of hypotheses are related to the confidence level of managers during earnings conference calls. The first type of information we want to focus on is numerical information provided by managers. Compared with qualitative information, quantitative information tends to be more precise and more difficult to change in the future (Bertomeu and Marinovic, 2015). Thus, numerical information in earnings conference calls embed more litigation and reputational risks than other less precise information. Zhou (2017) also argues that the percentage of quantitative information represents a manager's confidence for future firm performance. In terms of confidence level, we can also measure the uncertainty that managers express during an earnings conference call. As their confidence level decreases, managers will express more uncertainty in their words. If managers become more pessimistic during bad weather, they will be less willing to bear risk by stating less quantitative information and less willing to express confidence in their words spoken by increasing the level of uncertainty. We hypothesize that:

H2: Bad weather is negatively correlated with the use of numerical information by managers during earnings conference calls.

H3: Bad weather is positively correlated with the use of uncertainty words by managers during earnings conference calls.

For the second question regarding market reaction, previous research (Davis et al., 2015; Huang et al. 2014) has demonstrated that the market reacts to manager specific tone which is not related to firm fundamentals within an earnings conference call. Controlling for the level of tone and numerical content, we rely on our empirical results to determine the market reaction to bad weather during earnings conference calls. As a result, we hypothesize that:.

H4: Bad weather leads to a negative stock market reaction on the earnings conference call date. 
On the contrary, if investors know that managerial tone or numerical information are influenced by local weather conditions, the market is not expected to react to this change as these changes do not carry incremental value relevant information.

\section{Data}

Our analysis employs data from several sources. Our initial sample consists of all earnings conference call transcripts from Capital IQ from 2006 through 2017. We merge earnings conference call data ${ }^{2}$ with weather data from the Integrated Surface Database (ISD), which is available from the National Oceanic and Atmospheric Administration (NOAA). ${ }^{3}$

The ISD database contains hourly weather observations such as cloud cover, temperature, and sea pressure etc. from 1901 to 2017. As the focus of our study is U.S. firms, we collect the data from all active weather stations located in the U.S. ${ }^{4}$ The ISD database also provides the latitude and longitude coordinates of each weather station which makes the calculation of distance between weather station and firm headquarter possible.

We also obtain firm financial and analyst coverage information used to construct the control variables from Compustat and Institutional Brokers' Estimate System (I/B/E/S), respectively. For individual executive speech during earnings conference calls, we also use Execucomp to identify the position of each speaker with in the firm. We drop all firms which are headquartered outside of the United States and limit our sample to all conference calls with available weather and

\footnotetext{
${ }^{2}$ Firm headquarters information is from Capital IQ and location changes in headquarters are rare (roughly 150 headquarter changes for the whole sample period).

$3 \mathrm{ftp} / / / \mathrm{ftp} . \mathrm{ncdc}$.noaa.gov/pub/data/noaa

${ }^{4}$ We define a weather station as active if the station is operational during our sample period and provides the cloud cover measurement. The average number of concurrently active stations in our study is approximately 3600 .
} 
control variables. ${ }^{5}$ To be specific, we require each firm have available financial information in Compustat and stock price information from CRSP. For analyst coverage information, we include both firms with and without analyst coverage in our sample. ${ }^{6}$ Since earnings conference call data in Capital IQ are available widely beginning in 2006, we restrict our sample period to 2006-2017 and obtain a final sample of 57,374 firm-quarter level observations. ${ }^{7}$ To mitigate the effect of the outliers, we winsorize all continuous variables at the 1st and 99th percentiles.

\subsection{Weather-Induced Mood Measurement}

We follow prior research by measuring weather-induced mood using local cloud cover (e.g., Saunders 1993; Hirshleifer and Shumway 2003; DeHaan et al. 2017). The original cloud cover data from ISD is hourly sky coverage in oktas, where 0 oktas cover is a clear sky and 8 oktas cover is reported as full cloud coverage. ${ }^{8}$ We follow previous literature by taking the average of hourly cloud cover data during daytime which is from 6 am to $6 \mathrm{pm}$ (DeHaan et al. 2017). To overcome the seasonality of cloud cover in each city, we use the same method as Hirshleifer and Shumway (2003) to seasonally-adjust our cloud data. We first calculate the average cloud cover for each week of a given year for a given city in our sample period. Then, we take the average of the weekly mean in each city for the whole sample period to generate the historical weekly mean cloud cover during our sample period. At last, we subtract the historical weekly mean from our daily cloud cover measurement in that city on the day of the earnings conference call to obtain

\footnotetext{
${ }^{5}$ The omitted firms are not statistically different from firms in our final sample with respect to any of the variables in Table 1. In untabulated specifications, we replicate our regression results setting DCloud Cover to 0 for firms without weather data only to find similar results.

${ }^{6}$ For firms without analyst coverage, we set all analyst related control variables to 0 . Untabulated results are similar when we use only firms with analyst coverage.

${ }^{7}$ There are 5,389 firm-quarters (roughly $10 \%$ of our whole sample) without analyst coverage in I/B/E/S database.

${ }^{8}$ https://en.wikipedia.org/wiki/Okta
} 
the adjusted cloud cover where a higher number means poorer weather conditions. We defined this deseasonalized cloud cover measurement as Dcloud Cover.

After seasonally adjusting the cloud cover data, we match headquarters information for each firm with our Dcloud Cover data from all available weather stations within a 50-mile range of each firm's headquarters. ${ }^{9}$ We determine headquarters locations from Capital IQ and weather station data from ISD provides geographic coordinates information. ${ }^{10}$ The distance is calculated based on the longitude-latitude coordinates of the weather station and the central coordinates of the ZIP code for each firm. We then take the mean for all the weather stations with available cloud cover data in a 50-mile range around the firm's headquarters. To obtain an indicator variable for bad weather, we define Bad Weather equal to one when Dcloud Cover is larger than the median in our sample. ${ }^{11}$

One potential concern of the validity of this deseasonalized cloud cover data is that it may cluster in some specific city or state. In Figure 1, we plot a histogram of two specific cities and corresponding states which we presume to have the best (Miami) and worst (Seattle) weather conditions across the United States.

\section{[Insert Figure 1]}

As you can see from the histograms and corresponding tables, differences are not statistically significant. At the city level, Dcloud Cover is more concentrated around 0 for Miami and Dcloud Cover is more disperse for Seattle but the difference is not statistically significant. If

\footnotetext{
${ }^{9}$ Our results are robust to choosing 25 mile or 75 mile ranges.

${ }^{10}$ Capital IQ provides the ZIP code for each firm's headquarters information, then we use ZIP code to obtain coordinates data from United States Census (https://www.census.gov/geo/maps-data/data/gazetteer.html)

${ }^{11}$ Our results still hold when we use a continuous variable for cloud cover measurement.
} 
we look into the state level, the difference becomes even smaller. All of these results support the validity of our seasonally adjusted cloud cover measurement.

\subsection{Mood-Related Behavior}

An advantage of our approach is that we can observe and track more direct mood-related behavior during earnings conference calls. In particular, earnings conference calls provide the following advantages when compared to other executive activities such as tax avoidance and managerial forecasts. First, the date of the conference call is usually determined in advance which is uncorrelated to abnormal weather conditions. Second, the conference call occurs within a single day which gives us a clear, concise window for measurement of weather conditions. Third, the majority of conference call participants are communicated through audio only which mitigates any effects of information from facial or body expressions. All of these provide a clear setting for testing the relationship between weather and executive behavior.

Consistent with previous literature in finance and accounting in measuring the tone within earnings conference calls (e.g., Huang et al., 2014; Davis et.al., 2015), we rely on the Loughran and McDonald (2011) finance-oriented dictionaries to calculate net tone as a percentage of positive words minus the percentage of negative words and calculate uncertainty as a percentage of uncertainty words in the earnings conference call. ${ }^{12}$

$$
\begin{gathered}
\text { Net Tone }=\frac{\text { Positive Words }- \text { Negative Words }}{\text { Total Words }} \times 100 \\
\% \text { Uncertainty }=\frac{\text { Uncertainty Words }}{\text { Total Words }} \times 100
\end{gathered}
$$

\footnotetext{
${ }^{12}$ We also use Harvard IV-4 dictionaries to construct a similar measurement. These regression results are similar to those using the Loughran and McDonald (2011) financial dictionary.
} 
We only use net tone or uncertainty words from manager responses in the Q\&A section of each conference call which has shown to be less prepared in advance by previous studies (Allee and DeAngelis, 2015; Davis et al., 2015). The mean of our Net Tone in $Q \& A$ and \% Uncertainty in $Q \& A$ measurement is $0.69 \%$ and $0.91 \%$ which is similar to previous studies examining earnings conference call content (Call et al., 2017; Loughran and McDonald, 2011).

For the measurement of quantitative information, we use a similar method described by Zhou (2017). We count the number of numeric phrases in each transcript and exclude whole numbers from 1950 to 2020 to avoid including mention of years in the transcripts. The formula we use is:

$$
\% \text { Numbers }=\frac{\text { Total Numbers }}{\text { Total Words }+ \text { Total Numbers }} \times 100
$$

where Total Numbers is calculated using the method above and Total Words is the total count of all words in each transcript. ${ }^{13}$ Similar to the motivation for only using net tone in the Q\&A section, we also use numbers present only in management responses within the Q\&A section. We use \% Numbers in Q\&A as our variable to measure the percentage of quantitative information inside each earnings conference call. The mean for \% Numbers in Q\&A is $1.5 \%$ percent which is similar to Zhou's (2017) measurement.

\subsection{Other Control Variables}

We follow prior literature in selecting control variables (e.g., Davis et al., 2015; Zhou, 2017; Huang et al., 2014). We include two types of variables that will influence market reaction and executive language during earnings conference calls. The first type of control is related to firm status and financial performance in a given quarter. We control for Accruals which is calculated

\footnotetext{
${ }^{13}$ The total words measurement in Loughran and McDonald (2011) does not include numbers.
} 
as accruals relative to total assets, market capitalization $(\operatorname{Ln}($ Size $))$, Book to Market ratio, Return on Assets, Momentum which is calculated as the firm's lagged cumulative 12-month stock return, and Negative Earnings which is an indicator variable that equals one when the firm reports a negative earnings result in that quarter. The second type of control relates to pressure from outside stakeholders such as investors and analysts. The variables are Surprise Earnings ${ }^{14}$ which is the difference between actual earnings and consensus analyst forecast divided by the standard deviation of analyst forecast, number of analysts following the company in that quarter (Ln(Analysts)), number of earnings estimates made by analysts during that quarter (Ln(Revisions)), and an indicator variable to distinguish whether the firm met earnings expectation in that quarter (Meet Expectations).

In addition, we follow Chen et.al. (2018) by controlling for the time of day in which the conference call takes place. They conclude that the tone of conference call deteriorates markedly over the course of the day, and they attribute this negative relation to a decrease in energy level of executives. As a result, we create a dummy variable (Afternoon) to distinguish calls held before or after 12 noon. In our study, we find there are less than $40 \%$ of calls that begin in the afternoon which is similar to the number reported by Chen et al. (2018). Detailed definitions of all variables are provided in Appendix I.

\subsection{Summary Statistics}

Table 1 displays our sample summary statistics. Our variables are consistent with previous research (Davis et al., 2015; Zhou, 2017). The mean for Dcloud Cover is near zero, and its standard deviation is 2.59 which is similar to Hirshleifer and Shumway (2003). Further, the mean

\footnotetext{
${ }^{14}$ Our results are similar if we define Surprise Earnings by standardizing the difference between actual and forecasted earnings by the consensus forecast rather than the forecast standard deviation.
} 
cumulative abnormal return is around $0.105 \%$, the mean earnings surprise is 0.784 , and the mean momentum return is 0.126 . On average, our sample has 7.39 analysts following the firm and the mean number of revisions for each analyst is around 1.10. Our sample observations also have an average log-transformed firm size of 7.41 which translates into $\$ 1.65$ billion and an average book to market ratio of 0.566 . In addition, $8.9 \%$ of the observations report a loss in a given quarter and $67.8 \%$ of the observations meet the consensus analyst earnings forecast. ${ }^{15}$

\section{[Insert Table 1]}

\section{Empirical Results}

\subsection{Univariate Analysis}

We begin examining our research questions by conducting a univariate analysis of the relationship between weather conditions and mood-related behavior during earnings conference calls. As shown in Panel A of Table 2, the difference between net tone in good weather and bad weather is $0.058 \%$ which equals a $9 \%$ increase, and this number is also statistically significant at the $1 \%$ level. This significant difference is also seen for uncertainty words. There is a $0.03 \%$ difference in the usage of uncertainty words between the weather condition states. With respect to quantitative information, we can see that the percentage in good weather is $4 \%$ higher relative to that in bad weather. This number is also statistically significant at $1 \%$ level. We observe that the Q\&A of earnings calls are longer in bad weather than in good weather providing preliminary evidence that executives are more willing to talk more when weather-induced mood is negative.

\section{[Insert Table 2]}

\footnotetext{
15 The correlation between Meet Expectations and Negative Earnings is -0.23. Also, correlations between Surprise Earnings and Meet Expectation or Negative Earnings are only 0.011 and 0.003, respectively.
} 
Results in Panel A of Table 2 provide initial results that weather can affect manager behavior during earnings conference calls, but other variables are also different between firms during good and bad weather as shown in Panel B of Table 2. For market reaction, we use cumulative abnormal return between -1 days to +1 days around the call. We see that the difference is $-0.018 \%$ but is not significant. The insignificance is likely due to differences in firm characteristics. Among these differences, firms in bad weather tend to be larger, have a higher (lower) percentage of firm-quarters that meet market expectations (have negative earnings), have more estimate revisions, higher book to market ratios, and are more likely to hold calls in the afternoon. Many of these differences are likely to influence net tone, uncertainty, and number usage. To control for these time-variant firm variables, we use a multivariate regression analysis to examine the relationship between weather and behavior. In addition to firm and quarter fixed effects, we also use a matched-sample analysis to further test our hypotheses.

\subsection{Weather and Mood-Related Behavior}

As stated earlier, we predict that bad weather will influence executive mood-related behavior by decreasing net tone and numerical information and increasing the percentage of uncertainty words spoken by managers. We test these predictions using the following OLS model:

$$
\begin{aligned}
\text { Behavior }= & \alpha+\beta_{1} \text { Bad Weather }+\beta_{2} \operatorname{Ln}(\text { Size })+\beta_{3} \text { Book to Market }+\beta_{4} \text { Return on Assets } \\
& \left.+\beta_{5} \text { Surprise Earnings }+\beta_{6} \text { Ln }(\text { Analysts })+\beta_{7} \text { Ln (Revisions }\right) \\
& +\beta_{8} \text { Meet Expectations }+\beta_{9} \text { Afternoon }+\beta_{10} \text { Accruals }+\beta_{11} \text { Momentum } \\
& + \text { Firm FE }+ \text { CalendarQuarter FE }+\epsilon \quad(1)
\end{aligned}
$$

where the dependent variable, Behavior, is alternatively net tone (Net Tone in $Q \& A$ ), percentage of quantitative information (\% Numbers in $Q \& A$ ), or percentage of uncertainty words (\% Uncertainty in $Q \& A$ ) spoken by management in the conference call Q\&A section. To control for 
time invariant unobservable firm characteristics and times series variation, we also include firm and calendar quarter (e.g., first quarter, second quarter, etc.) fixed effects. ${ }^{16}$

\section{[Insert Table 3]}

The results reported in Table 3 show both the weather effects on net tone, which is presented in columns (1) and (2), and on the percentage of quantitative information which is shown in columns (3) and (4). The last two columns report results for uncertainty words usage. We use two model specifications for the three types of mood-related behavior. In column (1), (3), and (5), we regress net tone, percentage of numerical information, or the percentage of uncertainty words usage on an indicator variable for bad weather and include both firm and quarter fixed effects. In the remaining columns we further add all of our control variables. ${ }^{17}$

The coefficient for Bad Weather is negative and statistically significant at the $1 \%$ level across columns (1) to (4) and is positive and statistically significant at the $1 \%$ level in column (5) and (6) of Table 3. These results are consistent with our hypotheses which state that bad weather will decrease net tone and the percentage of quantitative information and will increase the percentage of uncertainty in the Q\&A section of the call. The result is not only statistically significant but also economically significant. Bad Weather decreases Net Tone in Q\&A (\% Numbers in $Q \& A)$ from its mean by $5 \%(2 \%)$ when we include control variables and fixed effects for both firm and quarter. Also, Bad Weather increases \% Uncertainty by $2 \%$.

The results for control variables are mainly consistent with prior studies (Davis et al., 2015; Zhou, 2017). Specifically, Net Tone for managers is higher for firms with larger size, positive

\footnotetext{
${ }^{16}$ Calendar quarter fixed effects also control for seasonal affective disorder (SAD), which is a recognized medical condition in which the shortness of the days in fall and winter leads to depression for some individuals.

${ }^{17}$ In an unreported table, we also replace firm fixed effects with CEO fixed effects. Our results still hold.
} 
earnings surprises, and more momentum of return in the past 12 months. Net Tone is lower for firms with a higher book to market ratio, more analyst coverage, and when the call is held in the afternoon. Similar control variable results are observed when the dependent variable is the percentage of quantitative information or uncertainty words. In the next subsection, we focus on our second question related to whether the market reacts to these weather-induced behavioral changes.

\subsection{Weather and Market Reaction}

If the market determines that tone or percentage of numbers are changed by weather conditions which are unrelated to current firm fundamentals, investors will not react to these changes if they are rational. However, previous research (Davis et al., 2015; Huang et al. 2014) has shown that the market reacts to manager-specific tone even if it is unrelated to firm performance. To test whether the market reacts to weather conditions, we employ the following regression:

$$
\begin{aligned}
\text { CAR }[-1,+1]= & \alpha+\beta_{1} \text { Bad Weather }+\beta_{2} \text { Net Tone in } Q \& A+\beta_{3} \% \text { Numbers in } Q \& A+\beta_{4} \operatorname{Ln}(\text { Size }) \\
& +\beta_{5} \text { Book to Market }+\beta_{6} \text { Return on Assets }+\beta_{7} \text { Surprise Earnings } \\
& \left.\left.+\beta_{8} \text { Ln (Analysts }\right)+\beta_{9} \text { Ln (Revisions }\right)+\beta_{10} \text { Meet Expectations }+\beta_{11} \text { Afternoon } \\
& +\beta_{12} \text { Accruals }+\beta_{13} \text { Momentum }+ \text { Firm FE }+ \text { CalendarQuarter FE }+\epsilon \quad(2)
\end{aligned}
$$

where CAR $[-1,+1]$ is the cumulative abnormal return around the earnings call date. The control variables are similar to equation (1) except we add two additional controls: Net Tone and \% Numbers. ${ }^{18}$ The results are shown in Table 4.

\section{[Insert Table 4]}

\footnotetext{
18 The reason that we include these two variables, and not uncertainty, is that only these two variables have been shown to significantly influence market reaction (e.g., Loughran and McDonald, 2011 and Zhou, 2017)
} 
We find the coefficient for Bad Weather to be negative and highly significant across all of the regression specifications in Table 4. In the first regression, we omit Net Tone in $Q \& A$ and $\%$ Numbers in $Q \& A$ as controls. After adding these controls, we observe that the coefficient for bad weather is still statistically significant at the $1 \%$ level in columns (2) and (3). In terms of economic significance, bad weather decreases the market reaction by $0.21 \%$ which translates into a \$20 million value reduction from firm mean market value in our sample. Control variables are consistent with prior research. These results provide initial evidence that weather effects firm returns in addition to the related changes in tone and percentage of quantitative information in earnings conference calls. We use a mediation test to further clarify this relationship.

\subsubsection{Mediation Test}

As we can see from Table 4, the coefficient for Bad Weather decreases in magnitude after adding Net Tone in $Q \& A$ and $\%$ Numbers in $Q \& A$. This may be initial evidence of a mediation effect since part of the weather effect is explained by Net Tone in $Q \& A$ and $\%$ Numbers in $Q \& A$. To apply a formal mediation test, we follow previous research (Baron and Kenny, 1986; Judd and Kenny, 1981; James and Brett,1984) and the four steps for establishing mediation. ${ }^{19}$

\section{[Insert Table 5]}

As shown in Panel A of Table 5, the effect of weather on market reaction may be mediated by the mediating variable (Net Tone in $Q \& A$ or $\%$ Numbers in $Q \& A$ ). To test this relationship, we must first show that the causal variable is correlated with the outcome variable which is path $\mathrm{C}$ in the graph. Then, we also need to demonstrate the correlation between the causal variable and the mediator is significant which is path A in the regression model. Third, we need to prove

\footnotetext{
${ }^{19}$ More information can be found on David A. Kenny's website: http://davidakenny.net/cm/mediate.htm
} 
that path B is significant by regressing our outcome variable on both the mediator and causal variable. Finally, we determine whether the mediator completely or partially mediates the relationship between the causal and outcome variable by looking at the significance of the causal variable. If the variable is insignificant, the mediation effect should be complete; otherwise, it is a partial mediation effect.

The formal test for mediation relationship is called the Sobel test (Sobel,1982):

$$
\text { Sobel Test }=\frac{\alpha_{a} \alpha_{b}}{\sqrt{\alpha_{a}^{2} \delta_{a}^{2}+\alpha_{b}^{2} \delta_{b}^{2}}}
$$

where $\alpha_{a}$ is the coefficient of Bad Weather in path A, $\delta_{a}$ is standard error of Bad Weather, $\alpha_{b}$ is the coefficient of Net Tone in $Q \& A$ or $\%$ Numbers in $Q \& A$ in path $\mathrm{B}$, and $\delta_{b}$ the standard error of $\alpha_{b}$ in path B. The result is shown in Panel $\mathrm{C}$ of Table 5. We test the mediation effect for each earnings call content variable separately and both are statistically significant. These analyses support the argument that net tone and percentage of numbers are mediators for the relationship between bad weather and market reaction. Additionally, the coefficient for Bad Weather is still significant after controlling for these conference call content variables when we look at the column (3) of Table 4.

This test supports the view that these two call content variables have a partial mediation effect on the relationship between bad weather and market reaction. To access the magnitude of this mediation effect, we need to compare the coefficient for Bad Weather before and after we added the mediator into the regression. In an unreported table, we estimate the mediation effect for Net Tone causes a $19 \%$ decrease of the Bad Weather indicator variable. The mediation effect for $\%$ Numbers causes a $2 \%$ decrease in of the Bad Weather indicator. Importantly, there is a 
large percentage of Bad Weather that cannot be explained by these two call content variables and represents the direct effect of bad weather on market reaction.

\subsection{Propensity Score Matching}

In this section, we seek to address a potential issue in our univariate analysis table that there may be significant differences in firm characteristics between firms that hold earnings calls in good and poor weather. To overcome this concern, we adopt a propensity-score matching (PSM) method to construct a balanced sample between firms in different weather conditions.

The first step of this PSM method is to construct the prediction model which is presented in Panel A of Table 6. The pseudo R-squared in this model is $0.7 \%$ which is low. The low predictive power in the first stage means our sample is more likely to represent a random subsample of the full population (Shipman, Swanquist, and Whited, 2017). This result supports any differences in firm characteristics associated with weather conditions during earnings conferences being a random effect and not due to an endogenous choice.

\section{[Insert Table 6]}

Panel B of Table 6 shows summary statistics for our matched sample. We have matched, without replacement, 26,356 firm-quarters observations with a corresponding control observation and the matching rate is approximately $92 \%$. The matching result works well since differences between our control variables in the treatment and control groups are not statistically significant.

We also rerun our main regression analysis examining the relationship between weather conditions and net tone, percentage of numbers, and market reaction respectively. All of these results are shown in Panel $\mathrm{C}$ of Table 6. These results are similar to those in Tables 3 and 4 
which indicates that our results are not driven by any differences in firm characteristics for earnings conference calls that occur during good or bad weather.

\subsection{Asymmetric Weather Effect}

In our previous analyses, we follow existing finance literature (Saunders, 1993; Hirshleifer and Shumway, 2003; deHann, Masden, and Piotrowski, 2017) and assume the weather effect on executives is symmetric, which means the relationship between the weather effect and the weather-induced mood change is linear. However, previous literature (Keller et.al, 2005) notess that weather effects on mood may be asymmetrical: the effect of bad weather on mood is more pronounced than good weather. Also, an earnings conference call is a voluntary disclosure method for the firm to release information to the public. This voluntary characteristic could make expressed sentiment positive as a default. As such, we predict that bad weather will have a larger effect on manager's behavior than good weather.

To test our prediction, we use a similar regression to equation (1) but replace the bad weather indicator variables with two indicator variables for weather conditions: Better Weather (bottom quartile in Dcloud Cover) and Worse Weather (top quartile in Dcloud Cover).

\section{[Insert Table 7]}

The first three columns in Table 7 report the results of this test. The magnitude of the coefficient for the worse weather indicator variable is larger for net tone, percentage of number used, and percentage of uncertainty words used which are shown in columns (1), (2), and (3), respectively. This result supports our prediction that bad weather is more pronounced than good weather in changing managers' behavior. 
We also examine whether the market reaction to weather conditions is symmetric or asymmetric. The result is shown in columns (4) and (5) of Table 7. The coefficient is significant for worse weather in column (4). However, after adding net tone and percentage of numbers used in column (5), we observe that the coefficient for Worse Weather decreases and is not different from zero.

\section{Robustness Checks}

In this section, we conduct a number of robustness checks to validate our main findings. The first set of robustness checks addresses the role of investor mood. Next, we mitigate the concern that our result may be driven by a small group of specific states since the three largest states that firms are headquartered in account for more than $36 \%$ of our entire sample.

\subsection{Investor Mood}

We consider the possibility that a negative market reaction is not due to changes in executives' mood but due to changes in investor and/or analyst mood. To address this concern, we employ two tests by controlling for sweather-induced mood of investors.

In the first test, we limit our sample to large firms since previous literature shows large firms have more geographically dispersed ownership (Coval and Moskowitz, 1999). As a result, a small firm may have a concentrated investor base which increases the probability that investors are near or in the same location as the firm's headquarters. We define a large firm as larger than the median asset size in our sample. The result is shown in column (1) of Table 8. The Bad Weather coefficient remains statistically and economically significant. ${ }^{20}$

\footnotetext{
${ }^{20}$ Untabulated robustness checks using other measures of ownership structure (HHI and institutional ownership percentage) yield similar results.
} 
[Insert Table 8]

Since previous studies demonstrate that weather around the New York Stock Exchange (NYSE) has a significant influence on stock returns (Saunders, 1993; Hirshleifer and Shumway,2003), our next robustness check controls for cloud cover level around New York City (NYC). The result is shown in column (2) of Table 8 and the coefficient for Dcloud Cover in NYC is negative and significant which is consistent with previous research (Saunders, 1993). The coefficient for Bad Weather remains negative and significant which is consistent with our previous results. Based on these two tests, our results are unlikely to be driven by investor mood changes.

\subsection{Major States}

To rule out the concern that our results are driven by specific states, we split our sample into two subsamples according to whether the firm is located in one of the largest three states since firms in the largest three states (NY, CA, and TX) account for more than $38 \%$ of our total sample. Column (3) of Table 8 shows the results for the remaining states and column (4) displays results for the firms in the largest three states. As one can see from these two columns, the coefficient for Bad Weather remains negative and significant in both subsamples.

\section{Additional Analysis}

In this section, we focus on the effect of weather conditions on individual executive roles (CEO or $\mathrm{CFO}$ ) and post-earnings announcement drift. Prior research in psychology suggests that the influence of mood on individuals' judgments is more pronounced in ambiguous settings (De Vries, Holland, and Witteman, 2008). As the CEO and CFO are responsible for different aspects

of the conference call, the weather effect on their mood-related behavior may be different. Panel A of Table 2 show the initial result that tone and numerical information spoken by CEOs are 
influenced by weather conditions. However, there is no clear relationship for CFOs. In order to get a clear relationship, we replace the dependent variable in equation (1) to Net Tone (\% Numbers or \% Uncertainty) for the CEO or CFO in Q\&A section respectively and rerun the regression analyses accordingly. As the appearance of the $\mathrm{CFO}$ (CEO) may influence the behavior of $\mathrm{CEO}$ (CFO), we further add two indicator variables to represent whether the CEO or CFO attends the earnings conference call (CEO Attends and CFO Attends).

\section{[Insert Table 9]}

In Table 9, we can see that the coefficients for the behavior of CEOs are all statistically significant and the sign of the coefficient is similar to our original results for all firm managers. The last three regressions in Table 9 are focused on CFO behavior. The coefficient for Bad Weather is not statistically significant in any of these three columns. These results indicate that CFO behavior is less affected by weather conditions than CEO behavior during earnings conference calls.

\subsection{Financial Expertise}

Some existing research argues that financial expertise may play an important role in dealing with mood-related behavioral differences. Chen et al. (2017b) argue that the impact of managerial mood on tax avoidance is mitigated in firms with more financial expertise within its board of directors. Financial knowledge may also help an executive to better understand the consequences of what he or she says during an earnings conference call on the firm's stock price. Compared to CEOs, CFOs may have more financial knowledge and perhaps also have a better understanding of the consequences of a negative earnings conference call. As a result, we hypothesize that differences in weather-induced behavior between a CEO and CFO are due to differences in executive financial expertise. To test the validity of this explanation, we focus on 
CEOs with financial expertise. Custodio and Metzger (2014) define a finance expert CEO as one who has previous experience in a finance related role - accountant, CFO, treasurer, or VP in finance - or in large auditing firms. ${ }^{21}$ We gather all data on managers' characteristics from Boardex and use the same definition as Custodio and Metzger (2014). In such, we find 11\% of our CEO sample has financial expertise. Next, we redo all of the regressions in Table 9 for CEOs by separating the whole CEO sample into two subgroups in Table 10: CEOs with financial expertise and CEOs without financial expertise.

[Insert Table 10]

The first two columns of Table 10 focus on the Net Tone usage for CEO in Q\&A section. However, we do not observe any significant difference in the coefficients between financial expert CEO and non-financial expert CEO. Column (3) and (4) show that the coefficient for Bad Weather is insignificant (significantly negative) for the subgroup of CEOs with (without) financial expertise and the difference between the two is also statistically significant. Results are similar when we switch our focus on uncertainty words usage in the last two columns. The Bad Weather coefficient is significantly positive only for CEOs without financial experience. The above results partially support a mitigating effect of financial knowledge on executive mood induced by poor weather conditions.

\subsection{Other Executive Characteristics}

We also look at three other dimensions of executives' characteristics -tenure, gender, and age - which previous research (Davis et al., 2015) shows can influence managerial behavior

\footnotetext{
${ }^{21}$ We use the definition of a financial related role as in Custodio and Metzger (2014). We focus on top-tier auditing firms: Pricewaterhouse, Deloitte, Ernst \& Young, KPMG, Arthur Andersen, Coopers, Peat Marwick, and Touche Ross. In an alternative measure of financial expertise, we find similar untabulated results using CEOs with MBA degrees according to Bertrand and Schoar (2003) and Ulrike and Tate (2005).
} 
during earnings conference calls. We use a similar strategy as above by separating our sample into two subgroups and examining any differences. For numerical characteristics (e.g. age, tenure), we use the top quartile point of the characteristic as the cut-off to separate each subgroup.

Previous research shows that women tend to exhibit less overconfidence and are less optimistic than men (Maccoby and Jacklin 1974; Price, 1993; Fellner and Maciejovsky 2007). We therefore expect female executives will be less affected by weather conditions. In terms of tenure, we use the number of years that an executive has served in the firm. For age, we simply use the actual age of executives from Execucomp. We predict longer tenure (old age) will decrease the weather effect since managers with more experience may adjust their tone accordingly. The results are displayed in Table $11 .^{22}$

\section{[Insert Table 11]}

In the first set of comparisons in Table 11, we examine net tone by manager characteristic and weather conditions. The results show that a manager's tone is affected by bad weather positively (negatively) when the executive is relatively new to the firm (has been with the firm for a longer period of time). The result is similar for age as old CEOs are more affected by the weather than young CEOs. These results are counter to our prediction that longer tenured CEOs (older CEOs) are better able to resist weather-induced mood effects. One possible explanation is that the weather effect is unconscious (Schwarz and Clore, 1983). When an individual is more familiar with his or her working environment or job responsibility, the unconscious effect of weather on mood may be stronger. Compared to male managers, female manager tone is

\footnotetext{
${ }^{22}$ We also test \% Numbers in the Q\&A section by individual executive but none of the coefficient differences are statistically significant. Due to the space constraints, we do not report these results in Table 11.
} 
positively affected by weather conditions. This is consistent with our prediction. In the second set of comparisons, we switch our focus to uncertainty words usage. We only observe significant result for gender in which female managers speak with less uncertainty than male managers when weather is bad. ${ }^{23}$

\subsection{Post-earnings Announcement Drift}

Our final analysis considers weather effects on post-earnings announcement drift (PEAD). PEAD reflects the tendency of a stock's cumulative returns to consistently drift in the direction of an earnings surprise in the weeks following an earnings announcement date (Ball and Brown, 1968; Bernard and Thomas, 1990). Previous research demonstrates that the tone of disclosure after an earnings announcement also influences PEAD (Feldman et al. 2010). Optimism or pessimism levels of a manager can also cause return to drift for a longer time period. As weather conditions will decrease a manager's view about the firm's future, we predict that poor weather conditions will decrease PEAD.

In Table 12 we use a similar regression model as equation (2) but add an interaction term between our Bad Weather indicator and Surprise Earnings. For the measurement of PEAD, we use the cumulative abnormal return in $[2,30],[2,45]$ and $[2,60]$ day windows after the earnings conference call.

\section{[Insert Table 12]}

As seen in Table 12, baseline PEAD is observed through positive and statistically significant coefficients for Surprise Earnings in columns (1) through (3). The coefficients for Bad Weather

\footnotetext{
${ }^{23}$ In unreported results, we also examine the role of managerial characteristics for individual executives (CEO or $\mathrm{CFO}$ ). We find that male CEOs speak with more uncertainty words and more negative net tone than female CEOs during bad weather. All the other executive role-based differences in managerial characteristics are insignificant.
} 
are negative and statistically significant across all specifications. These negative and significant results indicate that bad weather on the earnings call date will decrease PEAD after controlling for net tone and numerical content. Importantly, we see that the interaction term between $\mathrm{Bad}$ Weather and Surprise Earnings is negative and statistically significant at the $1 \%$ level. This result suggests that managerial mood-changes induced by bad weather also significantly change market interpretation of earnings surprises.

\section{Conclusion}

We examine the relationship between weather conditions and managerial behavior during earnings conference calls. We find that bad weather decreases net tone and quantitative information and increases the percentage of uncertainty words used by executives during earnings conference calls. This relationship can be attributed to weather effects on managerial mood. To be specific, bad weather makes managers more pessimistic about a firm's future and thus, they use a more negative tone, less precise information, and more uncertain language during earnings conference calls.

We further look at individual executive roles to confirm whether financial expertise mitigates behavioral bias induced by weather conditions. We find that, unlike CEOs, CFO behavior is not affected by weather conditions. This result is consistent with previous research (Chen et al., 2017b). We also confirm our result by examining a subsample of CEOs with prior experience in financial roles. We find that call content from these executives is not affected by weather conditions. In addition, we also consider other characteristics of executives. We find short-tenured and female executives are less affected by weather-induced mood changes.

We also examine market reactions to weather-induced behavior and find lower firm stock returns following earnings conference calls held during poor weather conditions. We then use the 
Sobel test to confirm net tone and percentage of numbers as two mediators in this relationship. In our robustness checks, we confirm that our results are not driven by investor mood or states where large numbers of firms are headquartered. In our PEAD analysis, we find significantly negative results which suggest that investors should consider weather conditions as a factor when they are evaluating managerial behavior during earnings conference calls.

Finally, we find that the coefficient for bad weather is still significant, albeit with a slightly smaller absolute value, after controlling for net tone (20\% reduction) and percentage of numbers (3\%) within an earnings conference call. Existing research has determined that the market reacts not only to the content of the call but to vocal cues from managers (Mayew and Venkatachalam, 2012). Future research might explore other components or factors inside earnings conference calls that may be influenced by weather conditions. 


\section{References}

Allee, Kristian, and Matthew Deangelis, 2015, The Structure of Voluntary Disclosure Narratives: Evidence from Tone Dispersion, Journal of Accounting Research 53, 241-247.

Akerlof, G. A., Shiller, R. J., 2009. Animal spirits: How human psychology drives the economy, and why it matters for global capitalism. Princeton: Princeton University Press

Antoniou, Constantinos, Alok Kumar, and Anastasios Maligkris, Terrorist Attacks, Sentiment, and Corporate Policies, 2016.

Ball, Ray, and Philip Brown, 1968, An empirical evaluation of accounting income numbers, Journal of accounting research, 159-178.

Baron, Reuben M., and David A. Kenny, 1986, The Moderator-Mediator Variable Distinction in Social Psychological Research. Conceptual, Strategic, and Statistical Considerations, Journal of Personality and Social Psychology 51, 1173-1182.

Bertomeu, Jeremy, and Iván Marinovic, 2016, A Theory of Hard and Soft Information, Accounting Review 91, 1-20.

Bertrand, Marianne, and Antoinette Schoar, 2003, Managing with style: The effect of managers on firm policies, The Quarterly Journal of Economics 118, 1169-1208.

Bower, Gordon H., 1983, Mood and Memory, American Psychologist, 370.

Bushee, Brian J., and Henry L. Friedman, 2016, Disclosure standards and the sensitivity of returns to mood, Review of Financial Studies 29, 787-822.

Call, Andrew, Nate Sharp, and Thomas Shohfi, 2017. Implications of Buy-Side Analysts' Participation in Public Earnings Conference Calls. SSRN Working Paper.

Carlson, Michael, Ventura Charlin, and Norman Miller, 1988, Positive mood and helping behavior: A test of six hypotheses, Journal of Personality and Social Psychology 55, 211-229.

Chen, Chen, and Yangyang Chen, 2017a, Managerial Mood and Earnings Forecast Bias: Evidence from Sunshine Exposure, SSRN Electronic Journal.

Chen, Jing, Elizabeth Demers, and Baruch Lev, 2018, Oh What a Beautiful Morning! Diurnal Influences on Executives and Analysts: Evidence from Conference Calls, Management Science, mnsc.2017.2888.

Chen, Yangyang, Rui Ge, Jeffrey A. Pittman, Madhu Veeraraghavan, and Leon Zolotoy, 2017b, Obscured by Clouds: The Impact of Weather-induced Managerial Mood on Corporate Tax Avoidance, SSRN Electronic Journal.

Chhaochharia, Vidhi, Dasol Kim, George M Korniotis, and Alok Kumar, 2017, Mood, firm behavior, and aggregate economic outcomes. SSRN Electronic Journal.

Cortés, Kristle, Ran Duchin, and Denis Sosyura, 2016, Clouded judgment: The role of sentiment in credit origination, Journal of Financial Economics 121, 392-413. 
Coval, Joshua D., and Tobias J. Moskowitz, 1999, Home bias at home: Local equity preference in domestic portfolios, Journal of Finance 54, 2045-2073.

Cunningham, Michael R., 1979, Weather, mood, and helping behavior: Quasi experiments with the sunshine samaritan, Journal of Personality and Social Psychology 37, 1947-1956.

Custódio, Cláudia, and Daniel Metzger, 2014, Financial expert CEOs: CEO’s work experience and firm's financial policies, Journal of Financial Economics 114, 125-154.

Davis, Angela K., Weili Ge, Dawn Matsumoto, and Jenny Li Zhang, 2015, The effect of manager-specific optimism on the tone of earnings conference calls, Review of Accounting Studies 20, 639-673.

de Vries, Marieke, Rob Holland, and Cilia Witteman, 2008, Fitting decisions: Mood and intuitive versus deliberative decision strategies, Cognition and Emotion 22, 931-943.

Dehaan, Ed, Joshua Madsen, and Joseph D. Piotroski, 2017, Do Weather-Induced Moods Affect the Processing of Earnings News?, Journal of Accounting Research 55, 509-550.

Druz, Marina, Alexander F Wagner, and Richard J Zeckhauser, 2015, Reading managerial tone: How analysts and the market respond to conference calls. SSRN Working Paper

Feldman, Ronen, Suresh Govindaraj, Joshua Livnat, and Benjamin Segal, 2010, Management's tone change, post earnings announcement drift and accruals, Review of Accounting Studies 15, 915-953

Fellner, Gerlinde, and Boris Maciejovsky, 2007, Risk attitude and market behavior: Evidence from experimental asset markets, Journal of Economic Psychology 28, 338-350.

Forgas, Joseph P., and Gordon H. Bower, 1987, Mood effects on person-perception judgments, Journal of Personality and Social Psychology 53, 53-60.

Goetzmann, William N, Dasol Kim, Alok Kumar, and Qin Wang, 2015, Weather-Induced Mood, Institutional Investors, and Stock Returns, The Review of Financial Studies 28, 73-111.

Goetzmann, William N., and Ning Zhu, 2005, Rain or shine: Where is the weather effect? European Financial Management 11, 559-578.

Hirshleifer, David, and Tyler Shumway, 2003, Good Day Sunshine: Stock Returns and the Weather, Journal of Finance 58, 1009-1032.

Huang, Xuan, Siew Hong Teoh, and Yinglei Zhang, 2014, Tone management, Accounting Review 89, 1083-1113.

Isen, Alice M., Thomas E. Shalker, Margaret Clark, and Lynn Karp, 1978, Affect, accessibility of material in memory, and behavior: A cognitive loop?, Journal of Personality and Social Psychology 36, 1-12.

James, Lawrence R., and Jeanne M. Brett, 1984, Mediators, moderators, and tests for mediation, Journal of Applied Psychology 69, 307-321.

Johnson, Eric J., and Amos Tversky, 1983, Affect, generalization, and the perception of risk, Journal of Personality and Social Psychology 45, 20-31. 
Judd, Charles M., and David A. Kenny, 1981, Process analysis: Estimating Mediation in Treatment Evaluations, Evaluation Review 5, 602-619.

Keller, Matthew C, Barbara L Fredrickson, Oscar Ybarra, Stéphane Côté, Kareem Johnson, Joe Mikels, Anne Conway, and Tor Wager, 2005, A warm heart and a clear head: The contingent effects of weather on mood and cognition, Psychological science 16, 724-731.

Keynes, J. M. 1936. The General Theory of Employment, Interest and Money. London: Palgrave Macmillan.

Lam, Raymond W., Anthony J. Levitt, Robert D. Levitan, Murray W. Enns, Rachel Morehouse, Erin E. Michalak, and Edwin M. Tam, 2006, The can-SAD study: A randomized controlled trial of the effectiveness of light therapy and fluoxetine in patients with winter seasonal affective disorder, American Journal of Psychiatry 163, 805-812.

Lambert, Gavin W., C. Reid, D. M. Kaye, G. L. Jennings, and M. D. Esler, 2002, Effect of sunlight and season on serotonin turnover in the brain, Lancet 360, 1840-1842.

Loughran, Tim, and Bill Mcdonald, 2011, When is a Liability not a Liability? Textual Analysis, Distionaries, and 10-Ks, Journal of Finance 66, 35-65.

Loughran, Tim, and Bill Mcdonald, 2016, Textual Analysis in Accounting and Finance: A Survey, Journal of Accounting Research 54, 1187-1230.

Maccoby, Eleanor E, and Carol Nagy Jacklin, 1978, The Psychology of Sex Differences. Vol. 2 (Stanford University Press).

Malmendier, Ulrike, and Geoffrey Tate, 2005, CEO overconfidence and corporate investment. Journal of Finance 60, 2661-2700.

Malmendier, Ulrike, Geoffrey Tate, and Jon Yan, 2011, Overconfidence and early-life experiences: the effect of managerial traits on corporate financial policies, The Journal of finance 66, 1687-1733.

Mayew, William J., and Mohan Venkatachalam, 2012, The power of voice: Managerial affective states and future firm performance, Journal of Finance 67, 1-44.

Parrott, W. Gerrod, and John Sabini, 1990, Mood and memory under natural conditions: Evidence for mood incongruent recall. Journal of Personality and Social Psychology 59, $321-336$.

Paternoster, Raymond, Robert Brame, Paul Mazerolle, and Alex Piquero, 1998, Using the correct statistical test for the equality of regression coefficients, Criminology 36, 859-866.

Peterson, Christopher, 2000, The future of optimism, American Psychologist 55, 44-55.

Prince, Melvin, 1993, Women, men, and money styles., Journal of economic Psychology.

Saunders, Edward M, 1993, Stock prices and Wall Street weather, American Economic Review $83,1337-1345$. 
Schwarz, Norbert, and Gerald L. Clore, 1983, Mood, misattribution, and judgments of wellbeing: Informative and directive functions of affective states, Journal of Personality and Social Psychology 45, 513-523.

Scott, Jamie M, 2007, The Impact of Weather Conditions on Mood Variability in Geographically Relocated Versus Non-Relocated Individuals.

Shipman, Jonathan E., Quinn T. Swanquist, and Robert L. Whited, 2017, Propensity score matching in accounting research, Accounting Review 92, 213-244.

Sobel, Michael E., 1982, Asymptotic Confidence Intervals for Indirect Effects in Structural Equation Models, Sociological Methodology 13, 290.

Spindelegger, Christoph, Patrycja Stein, Wolfgang Wadsak, Martin Fink, Markus Mitterhauser, Ulrike Moser, Markus Savli, Leonhard Key Mien, Elena Akimova, Andreas Hahn, Matthaeus Willeit, Kurt Kletter, Siegfried Kasper, and Rupert Lanzenberger, 2012, Lightdependent alteration of serotonin-1A receptor binding in cortical and subcortical limbic regions in the human brain, World Journal of Biological Psychiatry 13, 413-422.

Tversky, Amos, and Daniel Kahneman, 1973, Availability: A heuristic for judging frequency and probability, Cognitive Psychology 5, 207-232.

Zhou, Dexin, 2017, Do Numbers Speak Louder Than Words? SSRN Working Paper.

Zhou, Dexin, 2014, The Blame Game, SSRN Working Paper. 
Table 1

\section{Descriptive Statistics}

This table presents summary statistics for all variables in our sample. The sample period is 2006-2017. Detailed definitions for each variable are provided in Appendix I. All continuous variables are winsorized at $1 \%$ and $99 \%$ level.

\begin{tabular}{|c|c|c|c|c|c|c|}
\hline VARIABLES & $\mathrm{N}$ & Mean & Std Dev & Q1 & Median & Q3 \\
\hline Dcloud Cover & 57,374 & 0.021 & 2.593 & -1.913 & -0.722 & 1.726 \\
\hline Accruals & 57,374 & 0.004 & 0.105 & 0.000 & 0.016 & 0.044 \\
\hline Afternoon & 57,374 & 0.357 & 0.479 & 0.000 & 0.000 & 1.000 \\
\hline Bad Weather & 57,374 & 0.502 & 0.500 & 0 & 1 & 1 \\
\hline Book to Market & 57,374 & 0.566 & 0.477 & 0.254 & 0.466 & 0.766 \\
\hline CARs $[-1,1]$ & 57,369 & 0.105 & 8.218 & -4.038 & 0.045 & 4.299 \\
\hline CEO Attend & 57,374 & 0.723 & 0.447 & 0 & 1 & 1 \\
\hline CFO Attend & 57,374 & 0.673 & 0.469 & 0 & 1 & 1 \\
\hline Dcloud Cover in NYC & 56,282 & 1.118 & 2.629 & -1.113 & 0.328 & 3.375 \\
\hline Financial Expert CEO & 57,374 & 0.108 & 0.310 & 0 & 0 & 0 \\
\hline Ln(Analysts) & 57,374 & 1.991 & 0.857 & 1.386 & 2.079 & 2.639 \\
\hline Ln(Revisions) & 57,374 & 0.084 & 0.433 & 0.000 & 0.057 & 0.330 \\
\hline $\operatorname{Ln}($ Size $)$ & 57,374 & 7.411 & 1.929 & 6.019 & 7.387 & 8.697 \\
\hline Meet Expectation & 57,374 & 0.678 & 0.467 & 0 & 1 & 1 \\
\hline Momentum & 57,374 & 0.126 & 0.458 & -0.144 & 0.086 & 0.321 \\
\hline Negative Earnings & 57,374 & 0.189 & 0.391 & 0 & 0 & 0 \\
\hline Net Tone in Q\&A & 57,374 & 0.687 & 0.668 & 0.248 & 0.670 & 1.103 \\
\hline Net Tone from CEO & 41,171 & 0.849 & 0.863 & 0.292 & 0.803 & 1.355 \\
\hline Net Tone from CFO & 36,005 & 0.388 & 1.019 & -0.060 & 0.326 & 0.952 \\
\hline \% Numbers in Q\&A & 57,374 & 1.467 & 0.709 & 0.960 & 1.369 & 1.878 \\
\hline$\%$ Numbers from CEO & 41,172 & 1.286 & 0.822 & 0.699 & 1.149 & 1.728 \\
\hline$\%$ Numbers from CFO & 36,013 & 2.378 & 1.891 & 1.187 & 1.988 & 3.106 \\
\hline \% Uncertainty in Q\&A & 57,374 & 0.911 & 0.364 & 0.659 & 0.879 & 1.126 \\
\hline$\%$ Uncertainty from CEO & 41,171 & 0.868 & 0.456 & 0.559 & 0.819 & 1.122 \\
\hline$\%$ Uncertainty from CFO & 36,005 & 0.959 & 0.746 & 0.472 & 0.855 & 1.304 \\
\hline PEAD $[2,30]$ & 57,153 & 0.180 & 11.900 & -5.871 & -0.057 & 5.644 \\
\hline PEAD $[2,45]$ & 57,155 & 0.026 & 15.420 & -7.627 & -0.207 & 7.168 \\
\hline PEAD $[2,60]$ & 57,155 & 0.001 & 0.046 & 0.000 & 0.009 & 0.020 \\
\hline Return on Asset & 57,374 & 0.784 & 3.160 & -0.489 & 0.363 & 1.830 \\
\hline Surprise Earnings & 57,374 & 0.784 & 3.160 & -0.489 & 0.363 & 1.830 \\
\hline Total Words & 57,374 & 6,473 & 2,125 & 4,868 & 6,484 & 8,007 \\
\hline Total Words in Pre & 57,374 & 3,784 & 1,746 & 2,469 & 3,707 & 4,966 \\
\hline Total Words in Q\&A & 57,374 & 2,691 & 1,325 & 1,687 & 2,594 & 3,563 \\
\hline
\end{tabular}




\section{Table 2}

\section{Univariate Analysis}

This table shows univariate analyses for major variables in our sample. We separate our sample into two groups according to the deseasonalized cloud cover around the headquarters of the company during the date of each earnings conference call. Bad weather equals one when the deseasonalized cloud cover is larger than the median level in our sample. Panel A presents the comparison of variables related to conference calls. Panel B lists all non-textual variables. Detailed definitions for each variable are provided in Appendix I. Significance level: $* * *$ $\mathrm{p}<0: 01, * * \mathrm{p}<0: 05, * \mathrm{p}<0: 1$

\begin{tabular}{|c|c|c|c|c|c|c|c|c|}
\hline \multirow[b]{2}{*}{ VARIABLES } & \multicolumn{3}{|c|}{ Bad Weather=1 } & \multicolumn{3}{|c|}{ Bad Weather $=0$} & \multirow[b]{2}{*}{ Diff } & \multirow[b]{2}{*}{ T-stats } \\
\hline & $\mathrm{N}$ & Mean & Std Dev & $\mathrm{N}$ & Mean & Std Dev & & \\
\hline \multicolumn{9}{|l|}{ Panel A: Textual Variables } \\
\hline$\overline{\text { Net Tone in Q\&A }}$ & 28,801 & 0.658 & 0.671 & 28,573 & 0.716 & 0.663 & $-0.058 * * *$ & -10.414 \\
\hline$\%$ Numbers in Q\&A & 28,801 & 1.436 & 0.708 & 28,573 & 1.497 & 0.709 & $-0.061 * * *$ & -10.311 \\
\hline$\%$ Uncertainty in Q\&A & 28,801 & 0.926 & 0.365 & 28,573 & 0.896 & 0.361 & $0.030 * * *$ & 9.898 \\
\hline Net Tone from CEO & 19,137 & 0.826 & 0.870 & 22,034 & 0.870 & 0.857 & $-0.044 * * *$ & -5.154 \\
\hline$\%$ Numbers from CEO & 19,138 & 1.261 & 0.826 & 22,034 & 1.308 & 0.818 & $-0.047 * * *$ & -5.785 \\
\hline$\%$ Uncertainty from CEO & 19,137 & 0.883 & 0.464 & 22,034 & 0.856 & 0.448 & $0.027 * * *$ & 5.984 \\
\hline Net Tone from CFO in Q\&A & 16,648 & 0.381 & 1.014 & 19,357 & 0.394 & 1.024 & -0.013 & -1.207 \\
\hline$\%$ Numbers from CFO & 16,654 & 2.364 & 1.890 & 19,359 & 2.390 & 1.892 & -0.026 & -1.301 \\
\hline$\%$ Uncertainty from $\mathrm{CFO}$ & 16,648 & 0.971 & 0.743 & 19,357 & 0.950 & 0.749 & $0.021 * * *$ & 2.664 \\
\hline Total Words & 28,801 & 6,520 & 2,133 & 28,573 & 6,427 & 2,115 & $93.000 * * *$ & 5.244 \\
\hline Total Words in Pre & 28,801 & 3,808 & 1,746 & 28,573 & 3,760 & 1,746 & $48.000 * * *$ & 3.292 \\
\hline Total Words in Q\&A & 28,801 & 2,701 & 1,327 & 28,573 & 2,682 & 1,322 & $19.000 * * *$ & 1.718 \\
\hline \multicolumn{9}{|l|}{ Panel B: Non-Textual Variables } \\
\hline Accruals & 28,801 & 0.007 & 0.101 & 28,573 & 0.001 & 0.109 & $0.006^{* * *}$ & 7.145 \\
\hline Afternoon & 28,801 & 0.334 & 0.472 & 28,573 & 0.380 & 0.485 & $-0.046^{* * *}$ & -11.512 \\
\hline Book to Market & 28,801 & 0.592 & 0.494 & 28,573 & 0.539 & 0.458 & $0.053 * * *$ & 13.327 \\
\hline CARs $[-1,1]$ & 28,798 & 0.096 & 8.230 & 28,571 & 0.114 & 8.206 & -0.018 & -0.259 \\
\hline CEO Attend & 28,801 & 0.671 & 0.470 & 28,573 & 0.777 & 0.417 & $-0.106^{* * *}$ & -28.580 \\
\hline CFO Attend & 28,801 & 0.620 & 0.485 & 28,573 & 0.727 & 0.445 & $-0.107 * * *$ & -27.538 \\
\hline Financial Expert CEO & 28,801 & 0.109 & 0.311 & 28,573 & 0.107 & 0.309 & 0.002 & 0.773 \\
\hline Ln (Analysts) & 28,801 & 1.991 & 0.850 & 28,573 & 1.991 & 0.864 & 0.000 & 0.000 \\
\hline Ln (Revisions) & 28,801 & 0.096 & 0.426 & 28,573 & 0.071 & 0.439 & $0.025 * * *$ & 6.949 \\
\hline Ln (Size) & 28,801 & 7.444 & 1.923 & 28,573 & 7.379 & 1.935 & $0.065^{* * *}$ & 4.036 \\
\hline Meet Expectation & 28,801 & 0.682 & 0.466 & 28,573 & 0.673 & 0.469 & $0.009 * * *$ & 2.306 \\
\hline Momentum & 28,801 & 0.111 & 0.462 & 28,573 & 0.141 & 0.454 & $-0.030 * * *$ & -7.845 \\
\hline Negative Earnings & 28,801 & 0.178 & 0.383 & 28,573 & 0.199 & 0.399 & $-0.021 * * *$ & -6.430 \\
\hline PEAD $[2,30]$ & 28,695 & 0.099 & 12.060 & 28,458 & 0.262 & 11.730 & -0.163 & -1.634 \\
\hline PEAD $[2,45]$ & 28,697 & -0.049 & 15.480 & 28,458 & 0.102 & 15.370 & -0.151 & -1.169 \\
\hline PEAD $[2,60]$ & 28,697 & -0.382 & 18.820 & 28,458 & -0.469 & 18.520 & 0.087 & 0.557 \\
\hline Return on Asset & 28,801 & 0.002 & 0.044 & 28,573 & 0.000 & 0.047 & $0.003 * * *$ & 7.015 \\
\hline Surprise Earnings & 28,801 & 0.787 & 3.154 & 28,573 & 0.782 & 3.167 & 0.005 & 0.189 \\
\hline
\end{tabular}


Table 3

\section{Weather and Managerial Mood}

This table shows multiple regression results for the relationship between weather conditions and managerial mood. We use three variables in the earnings conference call transcripts to represent managerial mood: net tone, percentage of numbers spoken, and percentage of uncertainty words. For columns (1), (3) and (5), we only add firm and calendar quarter fixed effect to determinate the base relationship between bad weather and each dependent variable. We add control variables, which are described in Appendix I, in columns (2), (4) and (6). Standard errors are clustered by firm and t-statistics are shown in parentheses. Significance level: $* * * p<0.01, * * p<0.05, * \mathrm{p}<0.1$.

\begin{tabular}{|c|c|c|c|c|c|c|}
\hline Dependent Variable & $\begin{array}{l}(1) \\
\text { Net Tone in } \\
\text { Q\&A }\end{array}$ & $\begin{array}{l}(2) \\
\text { Net Tone in } \\
\text { Q\&A }\end{array}$ & $\begin{array}{c}(3) \\
\text { \% Numbers in } \\
\text { Q\&A }\end{array}$ & $\begin{array}{c}(4) \\
\text { \% Numbers in } \\
\text { Q\&A }\end{array}$ & $\begin{array}{c}\text { (5) } \\
\text { \% Uncertainty in } \\
\text { Q\&A }\end{array}$ & $\begin{array}{c}\text { (6) } \\
\% \text { Uncertainty in } \\
\text { Q\&A }\end{array}$ \\
\hline Bad Weather & $\begin{array}{c}-0.059 * * * \\
(-11.109)\end{array}$ & $\begin{array}{c}-0.037 * * * \\
(-7.024)\end{array}$ & $\begin{array}{c}-0.046 * * * \\
(-8.325)\end{array}$ & $\begin{array}{c}-0.027 * * * \\
(-4.971)\end{array}$ & $\begin{array}{c}0.030 * * * \\
(10.104)\end{array}$ & $\begin{array}{c}0.021 * * * \\
(7.209)\end{array}$ \\
\hline Ln (Size) & & $\begin{array}{c}0.133 * * * \\
(11.426)\end{array}$ & & $\begin{array}{c}0.129 * * * \\
(10.229)\end{array}$ & & $\begin{array}{c}-0.071 * * * \\
(-11.761)\end{array}$ \\
\hline Book to Market & & $\begin{array}{c}-0.119 * * * \\
(-7.938)\end{array}$ & & $\begin{array}{c}-0.104 * * * \\
(-6.840)\end{array}$ & & $\begin{array}{c}0.036 * * * \\
(5.199)\end{array}$ \\
\hline Return on Assets & & $\begin{array}{c}0.260 * * \\
(2.159)\end{array}$ & & $\begin{array}{c}-0.107 \\
(-0.882)\end{array}$ & & $\begin{array}{c}0.102 \\
(1.496)\end{array}$ \\
\hline Surprise Earnings & & $\begin{array}{c}0.010 * * * \\
(9.546)\end{array}$ & & $\begin{array}{c}0.001 \\
(0.542)\end{array}$ & & $\begin{array}{c}-0.001 * * \\
(-2.479)\end{array}$ \\
\hline Ln (Analysts) & & $\begin{array}{c}-0.044 * * * \\
(-4.068)\end{array}$ & & $\begin{array}{c}0.024 * * \\
(2.004)\end{array}$ & & $\begin{array}{c}0.019 * * * \\
(3.311)\end{array}$ \\
\hline Ln (Revisions) & & $\begin{array}{c}-0.103 * * * \\
(-11.000)\end{array}$ & & $\begin{array}{c}-0.023 * * \\
(-2.311)\end{array}$ & & $\begin{array}{c}0.021 * * * \\
(3.950)\end{array}$ \\
\hline Meet Expectations & & $\begin{array}{c}0.077 * * * \\
(11.197)\end{array}$ & & $\begin{array}{c}-0.017 * * \\
(-2.489)\end{array}$ & & $\begin{array}{c}-0.002 \\
(-0.406)\end{array}$ \\
\hline Negative Earnings & & $\begin{array}{c}-0.002 \\
(-0.169)\end{array}$ & & $\begin{array}{c}-0.004 \\
(-0.301)\end{array}$ & & $\begin{array}{l}-0.013^{*} \\
(-1.928)\end{array}$ \\
\hline Afternoon & & $\begin{array}{c}-0.048 * * * \\
(-3.030)\end{array}$ & & $\begin{array}{c}0.020 \\
(1.151)\end{array}$ & & $\begin{array}{c}0.008 \\
(0.887)\end{array}$ \\
\hline Accruals & & $\begin{array}{c}-0.084 \\
(-1.612)\end{array}$ & & $\begin{array}{c}0.025 \\
(0.473)\end{array}$ & & $\begin{array}{c}0.091 * * * \\
(3.229)\end{array}$ \\
\hline
\end{tabular}




\begin{tabular}{|c|c|c|c|c|c|c|}
\hline \multicolumn{2}{|l|}{ Momentum } & $\begin{array}{c}0.110 * * * \\
(15.326)\end{array}$ & & $\begin{array}{c}0.004 \\
(0.609)\end{array}$ & & $\begin{array}{c}-0.009 * * \\
(-2.393)\end{array}$ \\
\hline Constant & $\begin{array}{l}0.705^{* * *} * \\
(156.298)\end{array}$ & $\begin{array}{c}-0.184 * * \\
(-2.161)\end{array}$ & $\begin{array}{l}1.522 * * * \\
(317.110)\end{array}$ & $\begin{array}{c}0.577 * * * \\
(6.331)\end{array}$ & $\begin{array}{l}0.913 * * * \\
(360.551)\end{array}$ & $\begin{array}{l}1.385^{* * *} \\
(32.279)\end{array}$ \\
\hline Firm FE & YES & YES & YES & YES & YES & YES \\
\hline Quarter FE & YES & YES & YES & YES & YES & YES \\
\hline Observations & 57,374 & 57,374 & 57,374 & 57,374 & 57,374 & 57,374 \\
\hline Adjusted $\mathrm{R}^{2}$ & 0.312 & 0.338 & 0.366 & 0.372 & 0.305 & 0.310 \\
\hline
\end{tabular}


Table 4

\section{Weather and Market Reaction}

This table shows multiple regression results for the relationship between weather conditions and cumulative abnormal return ( -1 to +1 day) around each earnings conference call date. We include only Bad Weather, fixed effects, and control variables in column (1). For column (2), we add management net tone in the earnings call transcript Q\&A. We further add the percentage of numbers in each transcript as an additional control variable in column (3). Standard errors are clustered by firm and t-statistics are shown in parentheses. Detailed definitions for each variable are provided in Appendix I. Significance level: *** $\mathrm{p}<0: 01, * * \mathrm{p}<0: 05, * \mathrm{p}<0: 1$.

\begin{tabular}{|c|c|c|c|}
\hline Dependent Variable & $\begin{array}{c}(1) \\
\text { CAR }[-1,1] \\
\end{array}$ & $\begin{array}{c}(2) \\
\text { CAR }[-1,1] \\
\end{array}$ & $\begin{array}{c}(3) \\
\text { CAR }[-1,1]\end{array}$ \\
\hline Bad Weather & $\begin{array}{c}-0.261 * * * \\
(-3.728)\end{array}$ & $\begin{array}{c}-0.211 * * * \\
(-3.032)\end{array}$ & $\begin{array}{c}-0.208 * * * * \\
(-2.980)\end{array}$ \\
\hline Net Tone in Q\&A & & $\begin{array}{c}1.347 * * * \\
(19.067)\end{array}$ & $\begin{array}{c}1.356 * * * \\
(19.074)\end{array}$ \\
\hline$\%$ Numbers in Q\&A & & & $\begin{array}{c}0.119 * \\
(1.808)\end{array}$ \\
\hline Ln (Size) & $\begin{array}{c}-0.989 * * * \\
(-8.977)\end{array}$ & $\begin{array}{c}-1.168 * * * \\
(-10.538)\end{array}$ & $\begin{array}{c}-1.184 * * * \\
(-10.627)\end{array}$ \\
\hline Book to Market & $\begin{array}{c}1.441 * * * \\
(7.802)\end{array}$ & $\begin{array}{c}1.601 * * * \\
(8.629)\end{array}$ & $\begin{array}{c}1.614 * * * \\
(8.683)\end{array}$ \\
\hline Return on Assets & $\begin{array}{c}11.869 * * * \\
(5.722)\end{array}$ & $\begin{array}{c}11.517 * * * \\
(5.560)\end{array}$ & $\begin{array}{c}11.526^{* * * *} \\
(5.567)\end{array}$ \\
\hline Surprise Earnings & $\begin{array}{c}0.447 * * * \\
(23.131)\end{array}$ & $\begin{array}{c}0.433 * * * \\
(22.574)\end{array}$ & $\begin{array}{c}0.433 * * * \\
(22.569)\end{array}$ \\
\hline Ln (Analysts) & $\begin{array}{c}-0.569 * * * \\
(-4.719)\end{array}$ & $\begin{array}{c}-0.509 * * * \\
(-4.190)\end{array}$ & $\begin{array}{c}-0.511 * * * \\
(-4.210)\end{array}$ \\
\hline Ln (Revisions) & $\begin{array}{c}0.338 * * * \\
(2.749)\end{array}$ & $\begin{array}{c}0.477 * * * \\
(3.888)\end{array}$ & $\begin{array}{c}0.480 * * * \\
(3.918)\end{array}$ \\
\hline Meet Expectations & $\begin{array}{c}2.916 * * * \\
(27.003)\end{array}$ & $\begin{array}{c}2.813 * * * \\
(26.327)\end{array}$ & $\begin{array}{c}2.815 * * * \\
(26.342)\end{array}$ \\
\hline Negative Earnings & $\begin{array}{c}-0.045 \\
(-0.262)\end{array}$ & $\begin{array}{c}-0.042 \\
(-0.248)\end{array}$ & $\begin{array}{c}-0.041 \\
(-0.244)\end{array}$ \\
\hline Afternoon & $\begin{array}{c}-0.287 \\
(-1.635)\end{array}$ & $\begin{array}{c}-0.222 \\
(-1.267)\end{array}$ & $\begin{array}{c}-0.224 \\
(-1.279)\end{array}$ \\
\hline Accruals & $\begin{array}{c}-3.640 * * * \\
(-4.254)\end{array}$ & $\begin{array}{c}-3.526 * * * \\
(-4.109)\end{array}$ & $\begin{array}{c}-3.528 * * * * \\
(-4.113)\end{array}$ \\
\hline Momentum & $\begin{array}{c}-1.623 * * * \\
(-15.410)\end{array}$ & $\begin{array}{c}-1.772 * * * \\
(-16.796)\end{array}$ & $\begin{array}{c}-1.773 * * * \\
(-16.815)\end{array}$ \\
\hline Constant & $\begin{array}{c}6.181 * * * \\
(7.632)\end{array}$ & $\begin{array}{c}6.431 * * * \\
(7.915)\end{array}$ & $\begin{array}{c}6.362 * * * \\
(7.824)\end{array}$ \\
\hline
\end{tabular}


Firm FE

\section{YES}

Quarter FE

YES

57,369

0.0999

YES

YES

Observations

YES

YES

Adjusted R ${ }^{2}$

0.0999

57,369

57,369

0.108

0.108 


\section{Table 5}

\section{Mediation Test for Managerial Tone and Number Usage}

This table shows the mediation test among weather, managerial tone (managerial numbers usage), and market reaction. We employ a Sobel test to identify whether the effect of weather on market reaction is through managerial tone or number usage in Q\&A section. Panel A displays a graph to show the mediation relationship. We also introduce the basic steps to implicate the Sobel test in panel B. The results are shown in panel C. Significance level: $* * * p<0: 01, * * p<0: 05, * p<0: 1$.

Panel A: A Graph for Mediation Relationship

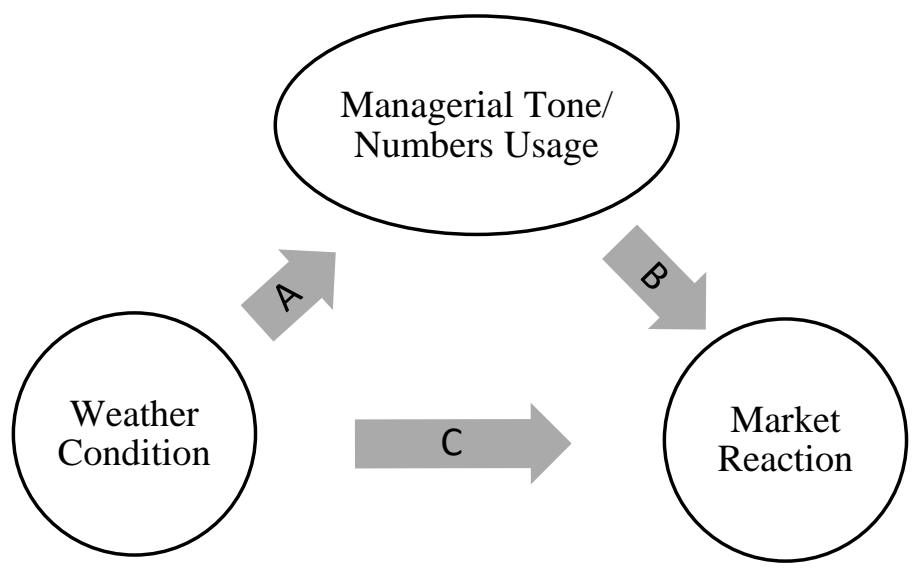

Panel B: Steps for Sobel Test

\begin{tabular}{cl}
\hline Steps & \multicolumn{1}{c}{ Description } \\
\hline 1st $\quad \begin{array}{l}\text { Path A: Run a regression analysis with the weather variable predicting the mediator } \\
\text { (managerial tone or managerial number usage) and calculate the coefficient and standard } \\
\text { errors for the mediator }\left(\alpha_{a}, \sigma_{a}\right)\end{array}$ \\
2nd $\quad \begin{array}{l}\text { Path B: Run a regression analysis with the weather variable and mediator predicting the } \\
\text { market reaction and calculate the coefficient and standard errors for the mediator }\left(\alpha_{b}, \sigma_{b}\right)\end{array}$ \\
Formula
\end{tabular}

Panel C: Sobel Test Results

\begin{tabular}{|c|c|c|c|c|}
\hline Mediator & \multicolumn{2}{|c|}{$\underline{\text { Net Tone }}$} & \multicolumn{2}{|c|}{ \% Numbers } \\
\hline Path & A & B & A & B \\
\hline Coefficient & -0.037 & 1.347 & -0.027 & 0.119 \\
\hline Std Dev & 0.005 & 0.071 & 0.005 & 0.066 \\
\hline Sobel Test & \multicolumn{2}{|c|}{$-6.894 * * *$} & \multicolumn{2}{|c|}{$--1.710^{*}$} \\
\hline p-value & \multicolumn{2}{|c|}{0.000} & \multicolumn{2}{|c|}{0.087} \\
\hline
\end{tabular}




\section{Table 6}

\section{Propensity Score Matching}

This table reports our main regression analysis based on a sample in which earnings conference calls held in bad weather is matched to calls held in good weather. We use one-to-one match without replacement. We successfully find a match for 26,356 earnings conference calls in bad weather which represents approximate $92 \%$ percent of our original earnings calls in bad weather. Panel A shows our logit model to determine the score. Panel B lists our matched sample statistics. The regression results for the matched sample are shown in Panel C. Standard errors are clustered by firm and t-statistics are shown in parentheses. Detailed definitions for each variable are provided in Appendix I. Significance level: *** $\mathrm{p}$ $<0: 01, * * \mathrm{p}<0: 05, * \mathrm{p}<0: 1$.

Panel A: Prediction Model

(1)

Dependent Variable Bad Weather

Ln (Size)

$-0.023^{* * *}$

Book to Market

$(-3.668)$

Book to Market

$0.210 * * *$

Return on Assets

(10.667)

Surprise Earnings

0.445

(1.237)

$-0.003$

Ln (Analysts)

$(-0.863)$

(Angysts)

0.016

(1.206)

Ln (Revisions)

$0.116^{* * * *}$

Meet Expectations

(5.816)

$0.058 * * *$

Negative Earnings

(2.582)

Negave Earings

$-0.086^{* * * *}$

Accruals

(-3.045)

Momentum

$-0.173 * * *$

(-9.486)

Afternoon

$0.307 * *$

(2.025)

Constant

$-0.112^{* * *}$

$(-5.759)$

$-0.044$

$(-0.986)$

Quarter FE

YES

Observations

57,374

Pseudo R-squared

0.00666 
Panel B: Summary Statistics for Matched Sample

\begin{tabular}{lccccc}
\hline Variables & Treated & Control & \%bias & t-statistics & p-value \\
\hline Ln (Size) & 7.428 & 7.429 & -0.100 & -0.06 & 0.95 \\
Book to Market & 0.558 & 0.557 & 0.200 & 0.21 & 0.836 \\
Return on Assets & 0.002 & 0.002 & 0.300 & 0.31 & 0.754 \\
Surprise Earnings & 0.792 & 0.792 & 0.000 & 0.00 & 0.996 \\
Ln (Analysts) & 1.999 & 1.996 & 0.300 & 0.34 & 0.732 \\
Ln (Revisions) & 0.082 & 0.084 & -0.500 & -0.60 & 0.549 \\
Meet Expectations & 0.680 & 0.679 & 0.200 & 0.24 & 0.808 \\
Negative Earnings & 0.182 & 0.183 & -0.100 & -0.17 & 0.866 \\
Accruals & 0.356 & 0.351 & 0.900 & 1.04 & 0.299 \\
Momentum & 0.006 & 0.006 & 0.600 & 0.69 & 0.492 \\
Afternoon & 0.128 & 0.128 & 0.000 & -0.03 & 0.975 \\
$\mathrm{~N}$ & 26356 & 26356 & & & \\
\hline
\end{tabular}

Panel C: Regression Result for Balanced Sample

\begin{tabular}{|c|c|c|c|c|}
\hline Dependent Variable & $\begin{array}{c}(1) \\
\text { Net Tone in } \\
\text { Q\&A } \\
\end{array}$ & $\begin{array}{c}\text { (2) } \\
\text { \% Numbers in } \\
\text { Q\&A }\end{array}$ & $\begin{array}{c}\text { (3) } \\
\% \text { Uncertainty in } \\
\text { Q\&A }\end{array}$ & $\begin{array}{c}(4) \\
\text { CAR }[-1,1]\end{array}$ \\
\hline Bad Weather & $\begin{array}{c}-0.037 * * * \\
(-6.888)\end{array}$ & $\begin{array}{c}-0.025^{* * *} * \\
(-4.480)\end{array}$ & $\begin{array}{c}0.021 * * * \\
(7.008)\end{array}$ & $\begin{array}{c}-0.237 * * * \\
(-3.237)\end{array}$ \\
\hline Net Tone & & & & $\begin{array}{l}1.339 * * * \\
(18.076)\end{array}$ \\
\hline$\%$ Numbers & & & & $\begin{array}{l}0.119^{*} \\
(1.727)\end{array}$ \\
\hline $\operatorname{Ln}($ Size $)$ & $\begin{array}{c}0.135 * * * \\
(11.444)\end{array}$ & $\begin{array}{c}0.134 * * * \\
(10.493)\end{array}$ & $\begin{array}{c}-0.073 * * * \\
(-11.917)\end{array}$ & $\begin{array}{c}-1.153 * * * \\
(-9.793)\end{array}$ \\
\hline Book to Market & $\begin{array}{c}-0.122 * * * \\
(-8.002)\end{array}$ & $\begin{array}{c}-0.104 * * * \\
(-6.382)\end{array}$ & $\begin{array}{c}0.039 * * * \\
(5.209)\end{array}$ & $\begin{array}{c}1.496 * * * \\
(7.633)\end{array}$ \\
\hline Return on Assets & $\begin{array}{c}0.280 * * \\
(2.187)\end{array}$ & $\begin{array}{c}-0.104 \\
(-0.839)\end{array}$ & $\begin{array}{l}0.121 * \\
(1.709)\end{array}$ & $\begin{array}{c}10.960 * * * \\
(5.025)\end{array}$ \\
\hline Surprise Earnings & $\begin{array}{c}0.011^{* * *} \\
(9.546)\end{array}$ & $\begin{array}{c}0.001 \\
(0.723)\end{array}$ & $\begin{array}{c}-0.001 * * \\
(-2.486)\end{array}$ & $\begin{array}{c}0.446 * * * \\
(22.541)\end{array}$ \\
\hline Ln(Analysts) & $\begin{array}{c}-0.039 * * * \\
(-3.559)\end{array}$ & $\begin{array}{c}0.018 \\
(1.475)\end{array}$ & $\begin{array}{c}0.019 * * * \\
(3.113)\end{array}$ & $\begin{array}{c}-0.545 * * * \\
(-4.310)\end{array}$ \\
\hline Ln(Revisions) & $\begin{array}{l}-0.101 * * * \\
(-10.303)\end{array}$ & $\begin{array}{l}-0.020 * \\
(-1.955)\end{array}$ & $\begin{array}{c}0.020 * * * \\
(3.595)\end{array}$ & $\begin{array}{c}0.502 * * * \\
(3.998)\end{array}$ \\
\hline Meet Expectations & $\begin{array}{c}0.075 * * * \\
(10.573)\end{array}$ & $\begin{array}{l}-0.014 * \\
(-1.904)\end{array}$ & $\begin{array}{c}0.000 \\
(0.040)\end{array}$ & $\begin{array}{c}2.796 * * * \\
(25.638)\end{array}$ \\
\hline Negative Earnings & 0.000 & -0.001 & -0.011 & 0.016 \\
\hline
\end{tabular}




\begin{tabular}{lcccc} 
& $(0.025)$ & $(-0.105)$ & $(-1.604)$ & $(0.092)$ \\
Afternoon & $-0.048 * * *$ & 0.018 & 0.006 & $-0.319 *$ \\
& $(-2.885)$ & $(0.993)$ & $(0.604)$ & $(-1.706)$ \\
Accruals & $-0.100 *$ & 0.033 & $0.079 * * *$ & $-3.578^{* * *}$ \\
& $(-1.832)$ & $(0.585)$ & $(2.606)$ & $(-3.968)$ \\
Momentum & $0.112 * * *$ & 0.004 & $-0.009 * *$ & $-1.771 * * *$ \\
Constant & $(15.020)$ & $(0.530)$ & $(-2.237)$ & $(-15.452)$ \\
& $-0.204 * *$ & $0.546^{* * *}$ & $1.399 * * *$ & $6.335 * * *$ \\
Firm FE & $(-2.375)$ & $(5.874)$ & $(31.816)$ & $(7.387)$ \\
Quarter FE & & & & \\
Observations & YES & YES & YES & YES \\
Adjusted R & YES & YES & YES & YES \\
\hline
\end{tabular}




\section{Table 7}

\section{Asymmetric Weather Effect}

This table examines asymmetric weather effects of both managers' behavior and market reaction. We use both Better Weather which accounts for the bottom quartile in our deseasonalized cloud cover variable and Worse Weather for the top quartile. The first three columns report the three manager behavior variables in the Q\&A section during earnings conference calls (net tone, percentage of numbers spoken, and percentage of uncertainty words spoken). The last two columns focus on the market reaction to these two weather indicator variables. Detailed definitions for each variable are provided in Appendix I. Standard errors are clustered by firm and t-statistics are shown in parentheses. Significance level: $* * * \mathrm{p}$ $<0: 01, * * \mathrm{p}<0: 05, * \mathrm{p}<0: 1$

\begin{tabular}{|c|c|c|c|c|c|}
\hline VARIABLES & $\begin{array}{c}(1) \\
\text { Net Tone in Q\&A }\end{array}$ & $\begin{array}{c}(2) \\
\% \text { Numbers in Q\&A }\end{array}$ & $\begin{array}{c}\text { (3) } \\
\text { \% Uncertainty in Q\&A }\end{array}$ & $\begin{array}{c}(4) \\
\text { CAR }[-1,1]\end{array}$ & $\begin{array}{c}(5) \\
\text { CAR }[-1,1]\end{array}$ \\
\hline Better Weather & $\begin{array}{c}0.009 \\
(1.525)\end{array}$ & $\begin{array}{c}0.003 \\
(0.542)\end{array}$ & $\begin{array}{c}-0.011 * * * \\
(-3.157)\end{array}$ & $\begin{array}{c}0.119 \\
(1.385)\end{array}$ & $\begin{array}{c}0.106 \\
(1.239)\end{array}$ \\
\hline Worse Weather & $\begin{array}{c}-0.038 * * * \\
(-6.241)\end{array}$ & $\begin{array}{c}-0.032 * * * \\
(-4.949)\end{array}$ & $\begin{array}{c}0.017 * * * \\
(4.807)\end{array}$ & $\begin{array}{l}-0.154^{*} \\
(-1.840)\end{array}$ & $\begin{array}{c}-0.098 \\
(-1.174)\end{array}$ \\
\hline Net Tone & & & & & $\begin{array}{l}1.357 * * * \\
(19.077)\end{array}$ \\
\hline$\%$ Numbers & & & & & $\begin{array}{l}0.120 * \\
(1.826)\end{array}$ \\
\hline Ln (Size) & $\begin{array}{c}0.131 * * * \\
(11.265)\end{array}$ & $\begin{array}{c}0.127 * * * \\
(10.066)\end{array}$ & $\begin{array}{c}-0.070 * * * \\
(-11.594)\end{array}$ & $\begin{array}{c}-0.984 * * * \\
(-8.890)\end{array}$ & $\begin{array}{c}-1.178 * * * \\
(-10.503)\end{array}$ \\
\hline Book to Market & $\begin{array}{c}-0.118 * * * \\
(-7.870)\end{array}$ & $\begin{array}{c}-0.103 * * * \\
(-6.786)\end{array}$ & $\begin{array}{c}0.036 * * * \\
(5.156)\end{array}$ & $\begin{array}{c}1.438 * * * \\
(7.779)\end{array}$ & $\begin{array}{c}1.609 * * * \\
(8.654)\end{array}$ \\
\hline Return on Assets & $\begin{array}{l}0.262 * * \\
(2.174)\end{array}$ & $\begin{array}{c}-0.106 \\
(-0.870)\end{array}$ & $\begin{array}{c}0.100 \\
(1.479)\end{array}$ & $\begin{array}{l}11.875 * * * \\
(5.724)\end{array}$ & $\begin{array}{l}11.528 * * * \\
(5.567)\end{array}$ \\
\hline Surprise Earnings & $\begin{array}{c}0.010 * * * \\
(9.552)\end{array}$ & $\begin{array}{c}0.001 \\
(0.552)\end{array}$ & $\begin{array}{l}-0.001 * * \\
(-2.474)\end{array}$ & $\begin{array}{c}0.447 * * * \\
(23.131)\end{array}$ & $\begin{array}{l}0.433 * * * \\
(22.567)\end{array}$ \\
\hline Ln (Analysts) & $\begin{array}{c}-0.044 * * * \\
(-4.040)\end{array}$ & $\begin{array}{c}0.024 * * \\
(2.034)\end{array}$ & $\begin{array}{l}0.019 * * * \\
(3.296)\end{array}$ & $\begin{array}{c}-0.569 * * * \\
(-4.718)\end{array}$ & $\begin{array}{c}-0.512 * * * \\
(-4.214)\end{array}$ \\
\hline Ln (Revisions) & $\begin{array}{c}-0.104 * * * \\
(-11.019)\end{array}$ & $\begin{array}{l}-0.023 * * \\
(-2.335)\end{array}$ & $\begin{array}{l}0.021 * * * \\
(3.982)\end{array}$ & $\begin{array}{c}0.334 * * * \\
(2.721)\end{array}$ & $\begin{array}{c}0.477 * * * \\
(3.895)\end{array}$ \\
\hline
\end{tabular}




\begin{tabular}{|c|c|c|c|c|c|}
\hline Meet Expectations & $\begin{array}{c}0.076 * * * \\
(11.170)\end{array}$ & $\begin{array}{c}-0.018 * * \\
(-2.503)\end{array}$ & $\begin{array}{c}-0.002 \\
(-0.392)\end{array}$ & $\begin{array}{c}2.916 * * * \\
(27.008)\end{array}$ & $\begin{array}{c}2.814 * * * \\
(26.345)\end{array}$ \\
\hline \multirow[t]{2}{*}{ Negative Earnings } & -0.002 & -0.004 & $-0.013^{*}$ & -0.043 & -0.040 \\
\hline & $(-0.161)$ & $(-0.295)$ & $(-1.937)$ & $(-0.251)$ & $(-0.235)$ \\
\hline \multirow[t]{2}{*}{ Afternoon } & $-0.048 * * *$ & 0.020 & 0.008 & $-0.289 *$ & -0.226 \\
\hline & $(-3.051)$ & $(1.138)$ & $(0.903)$ & $(-1.646)$ & $(-1.287)$ \\
\hline \multirow[t]{2}{*}{ Accruals } & -0.082 & 0.027 & $0.091 * * *$ & $-3.638 * * *$ & $-3.530 * * *$ \\
\hline & $(-1.570)$ & $(0.507)$ & $(3.193)$ & $(-4.252)$ & $(-4.114)$ \\
\hline \multirow[t]{2}{*}{ Momentum } & $0.111 * * *$ & 0.005 & $-0.009 * *$ & $-1.621 * * *$ & $-1.772 * * *$ \\
\hline & $(15.345)$ & $(0.641)$ & $(-2.404)$ & $(-15.386)$ & $(-16.796)$ \\
\hline \multirow[t]{2}{*}{ Constant } & $-0.179 * *$ & $0.584 * * *$ & $1.388 * * *$ & $6.033 * * *$ & $6.206 * * *$ \\
\hline & $(-2.110)$ & $(6.380)$ & $(32.180)$ & $(7.406)$ & $(7.580)$ \\
\hline Firm FE & YES & YES & YES & YES & YES \\
\hline Quarter FE & YES & YES & YES & YES & YES \\
\hline Observations & 57,374 & 57,374 & 57,374 & 57,369 & 57,369 \\
\hline Adjusted $\mathrm{R}^{2}$ & 0.338 & 0.372 & 0.310 & 0.0998 & 0.108 \\
\hline
\end{tabular}




\section{Table 8}

\section{Robustness Checks}

This table reports robustness checks for our regression results. To rule out investor sentiment, we focus on large firms which have been shown to have more diversified investor bases and the weather in New York City where most trading takes place. These results are listed in columns (1) and (2), respectively. The last set of analyses focus on the concern that our results are driven by some large states. We separate our sample into two subsamples based on firm headquarters located in one of the three largest states (NY, CA and TX) that have the most firms. These two subsample results are shown in columns (3) and (4). Detailed definitions for each variable are provided in Appendix I. Standard errors are clustered by firm and t-statistics are shown in parentheses. Significance level: $* * * p<0: 01, * * p<0: 05, * p<0: 1$.

\begin{tabular}{|c|c|c|c|c|}
\hline Dependent Variable & $\begin{array}{c}(1) \\
\text { Large Firm Subsample } \\
\text { CAR }[-1,1]\end{array}$ & $\begin{array}{c}(2) \\
\text { NYC Weather } \\
\text { CAR }[-1,1] \\
\end{array}$ & $\begin{array}{c}(3) \\
\text { Not NY,CA,TX } \\
\text { CAR }[-1,1] \\
\end{array}$ & $\begin{array}{c}\text { (4) } \\
\text { NY,CA,TX } \\
\text { CAR [-1,1] }\end{array}$ \\
\hline Bad Weather & $\begin{array}{c}-0.189 * * \\
(-2.293)\end{array}$ & $\begin{array}{c}-0.160 * * \\
(-2.145)\end{array}$ & $\begin{array}{c}-0.184 * * \\
(-2.115)\end{array}$ & $\begin{array}{c}-0.248 * * \\
(-2.135)\end{array}$ \\
\hline Net Tone & $\begin{array}{l}1.178 * * * \\
(13.242)\end{array}$ & $\begin{array}{l}1.345^{* * *} * \\
(18.727)\end{array}$ & $\begin{array}{c}1.318 * * * \\
(14.741)\end{array}$ & $\begin{array}{l}1.421 * * * \\
(12.130)\end{array}$ \\
\hline$\%$ Numbers & $\begin{array}{c}-0.087 \\
(-1.054)\end{array}$ & $\begin{array}{l}0.117^{*} \\
(1.754)\end{array}$ & $\begin{array}{l}0.154 * \\
(1.859)\end{array}$ & $\begin{array}{c}0.045 \\
(0.421)\end{array}$ \\
\hline Dcloud Cover in NYC & & $\begin{array}{c}-0.032 * * \\
(-2.229)\end{array}$ & & \\
\hline $\operatorname{Ln}($ Size $)$ & $\begin{array}{c}-1.047 * * * \\
(-7.036)\end{array}$ & $\begin{array}{c}-1.174 * * * \\
(-10.367)\end{array}$ & $\begin{array}{c}-1.221 * * * \\
(-8.110)\end{array}$ & $\begin{array}{c}-1.132 * * * \\
(-6.909)\end{array}$ \\
\hline Book to Market & $\begin{array}{c}1.261^{* * *} \\
(5.303)\end{array}$ & $\begin{array}{c}1.605^{* * *} \\
(8.563)\end{array}$ & $\begin{array}{c}1.468 * * * \\
(5.967)\end{array}$ & $\begin{array}{c}1.851 * * * \\
(6.628)\end{array}$ \\
\hline Return on Assets & $\begin{array}{c}13.040 * * * \\
(3.343)\end{array}$ & $\begin{array}{c}11.549 * * * \\
(5.498)\end{array}$ & $\begin{array}{c}8.272 * * * \\
(2.904)\end{array}$ & $\begin{array}{c}15.369 * * * \\
(5.093)\end{array}$ \\
\hline Surprise Earnings & $\begin{array}{c}0.414 * * * \\
(17.036)\end{array}$ & $\begin{array}{c}0.435 * * * \\
(22.377)\end{array}$ & $\begin{array}{c}0.438 * * * \\
(18.275)\end{array}$ & $\begin{array}{c}0.424 * * * \\
(13.336)\end{array}$ \\
\hline Ln(Analysts) & $\begin{array}{c}-0.654 * * * \\
(-4.053)\end{array}$ & $\begin{array}{c}-0.526 * * * \\
(-4.310)\end{array}$ & $\begin{array}{c}-0.437 * * * \\
(-2.736)\end{array}$ & $\begin{array}{c}-0.631 * * * \\
(-3.393)\end{array}$ \\
\hline
\end{tabular}




\begin{tabular}{|c|c|c|c|c|}
\hline Ln(Revisions) & $\begin{array}{c}0.707 * * * \\
(4.739)\end{array}$ & $\begin{array}{c}0.448 * * * \\
(3.645)\end{array}$ & $\begin{array}{c}0.469 * * * \\
(2.890)\end{array}$ & $\begin{array}{c}0.494 * * * \\
(2.666)\end{array}$ \\
\hline Meet Expectations & $\begin{array}{c}2.007 * * * \\
(16.332)\end{array}$ & $\begin{array}{c}2.801 * * * \\
(25.936)\end{array}$ & $\begin{array}{c}2.748 * * * \\
(20.741)\end{array}$ & $\begin{array}{c}2.931 * * * \\
(16.231)\end{array}$ \\
\hline Negative Earnings & $\begin{array}{c}0.284 \\
(1.113)\end{array}$ & $\begin{array}{c}-0.053 \\
(-0.313)\end{array}$ & $\begin{array}{c}-0.281 \\
(-1.251)\end{array}$ & $\begin{array}{c}0.294 \\
(1.146)\end{array}$ \\
\hline Afternoon & $\begin{array}{c}-0.411 * * \\
(-1.966)\end{array}$ & $\begin{array}{c}-0.204 \\
(-1.166)\end{array}$ & $\begin{array}{c}-0.242 \\
(-1.134)\end{array}$ & $\begin{array}{c}-0.156 \\
(-0.509)\end{array}$ \\
\hline Accruals & $\begin{array}{l}-3.216^{*} \\
(-1.833)\end{array}$ & $\begin{array}{c}-3.519 * * * \\
(-4.073)\end{array}$ & $\begin{array}{c}-3.528 * * * \\
(-3.036)\end{array}$ & $\begin{array}{c}-3.599 * * * \\
(-2.836)\end{array}$ \\
\hline Momentum & $\begin{array}{c}-1.909 * * * \\
(-14.204)\end{array}$ & $\begin{array}{c}-1.770 * * * \\
(-16.658)\end{array}$ & $\begin{array}{c}-1.943 * * * \\
(-14.934)\end{array}$ & $\begin{array}{c}-1.515 * * * \\
(-8.637)\end{array}$ \\
\hline Constant & $\begin{array}{c}8.516^{* * * *} \\
(6.440)\end{array}$ & $\begin{array}{c}6.355^{* * *} * \\
(7.701)\end{array}$ & $\begin{array}{c}6.821 * * * \\
(6.137)\end{array}$ & $\begin{array}{c}5.664 * * * \\
(4.775)\end{array}$ \\
\hline Firm FE & YES & YES & YES & YES \\
\hline Quarter FE & YES & YES & YES & YES \\
\hline Observations & 29,301 & 56,277 & 35,784 & 21,585 \\
\hline Adjusted $\mathrm{R}^{2}$ & 0.102 & 0.108 & 0.112 & 0.102 \\
\hline
\end{tabular}




\section{Table 9}

\section{Weather and Individual Executive's Mood}

This table shows multiple regression results for the relationship between weather conditions and individual executive's mood. We use three variables in the Q\&A section of earnings conference call transcripts to represent mood for CEO and CFO: net tone, percent of number spoken, and percentage of uncertainty words spoken. For columns (1), (2) and (3), we focus on CEO's behavior change. In column (4), (5), and (6), we switch our focus to CFO. Standard errors are clustered by firm and t-statistics are shown in parentheses. Detailed definitions for each variable are provided in Appendix I. Significance level: $* * * p<0: 01, * * p<0: 05, *$ p $<0: 1$.

\begin{tabular}{|c|c|c|c|c|c|c|}
\hline $\begin{array}{l}\text { Dependent } \\
\text { Variable }\end{array}$ & $\begin{array}{l}\text { (1) } \\
\text { Net Tone from } \\
\text { CEO }\end{array}$ & $\begin{array}{c}\text { (2) } \\
\text { \% Numbers from } \\
\text { CEO }\end{array}$ & $\begin{array}{c}\text { (3) } \\
\% \text { Uncertainty from } \\
\text { CEO }\end{array}$ & $\begin{array}{c}\text { (4) } \\
\text { Net Tone from } \\
\text { CFO }\end{array}$ & $\begin{array}{c}\text { (5) } \\
\text { \% Numbers from } \\
\text { CFO }\end{array}$ & $\begin{array}{c}(6) \\
\% \text { Uncertainty from } \\
\text { CFO }\end{array}$ \\
\hline Bad Weather & $\begin{array}{c}-0.017 * * \\
(-2.133)\end{array}$ & $\begin{array}{c}-0.025 * * * \\
(-3.353)\end{array}$ & $\begin{array}{c}0.015 * * * \\
(3.444)\end{array}$ & $\begin{array}{c}-0.001 \\
(-0.066)\end{array}$ & $\begin{array}{c}-0.004 \\
(-0.184)\end{array}$ & $\begin{array}{c}0.007 \\
(0.792)\end{array}$ \\
\hline CFO Attends & $\begin{array}{c}0.107 * * * \\
(5.992)\end{array}$ & $\begin{array}{c}-0.063 * * * \\
(-3.283)\end{array}$ & $\begin{array}{c}-0.021 * * \\
(-2.379)\end{array}$ & & & \\
\hline CEO Attends & & & & $\begin{array}{l}0.043 * \\
(1.649)\end{array}$ & $\begin{array}{c}0.044 \\
(0.969)\end{array}$ & $\begin{array}{l}-0.031 * \\
(-1.661)\end{array}$ \\
\hline Ln (Size) & $\begin{array}{c}0.107 * * * \\
(6.357)\end{array}$ & $\begin{array}{c}0.094 * * * \\
(5.569)\end{array}$ & $\begin{array}{c}-0.059 * * * \\
(-6.860)\end{array}$ & $\begin{array}{c}0.068 * * * \\
(2.681)\end{array}$ & $\begin{array}{c}0.002 \\
(0.048)\end{array}$ & $\begin{array}{c}-0.076 * * * \\
(-5.289)\end{array}$ \\
\hline Book to Market & $\begin{array}{c}-0.103 * * * \\
(-4.948)\end{array}$ & $\begin{array}{c}-0.125 * * * \\
(-5.623)\end{array}$ & $\begin{array}{c}0.049 * * * \\
(4.550)\end{array}$ & $\begin{array}{c}-0.106 * * * \\
(-3.778)\end{array}$ & $\begin{array}{l}-0.086 * \\
(-1.678)\end{array}$ & $\begin{array}{c}0.040 * * \\
(2.276)\end{array}$ \\
\hline Return on Assets & $\begin{array}{c}0.223 \\
(1.283)\end{array}$ & $\begin{array}{c}-0.092 \\
(-0.545)\end{array}$ & $\begin{array}{c}0.088 \\
(0.887)\end{array}$ & $\begin{array}{c}0.746 * * * \\
(2.607)\end{array}$ & $\begin{array}{c}-0.455 \\
(-0.934)\end{array}$ & $\begin{array}{c}0.088 \\
(0.403)\end{array}$ \\
\hline Surprise Earnings & $\begin{array}{c}0.008 * * * \\
(4.972)\end{array}$ & $\begin{array}{c}-0.001 \\
(-0.712)\end{array}$ & $\begin{array}{c}-0.001 \\
(-1.348)\end{array}$ & $\begin{array}{c}0.013 * * * \\
(5.920)\end{array}$ & $\begin{array}{c}0.004 \\
(1.045)\end{array}$ & $\begin{array}{c}-0.000 \\
(-0.272)\end{array}$ \\
\hline Ln (Analysts) & $\begin{array}{c}-0.092 * * * \\
(-5.863)\end{array}$ & $\begin{array}{l}0.026 * \\
(1.667)\end{array}$ & $\begin{array}{c}0.026 * * * \\
(3.016)\end{array}$ & $\begin{array}{c}-0.012 \\
(-0.604)\end{array}$ & $\begin{array}{c}0.019 \\
(0.463)\end{array}$ & $\begin{array}{l}0.037 * * \\
(2.570)\end{array}$ \\
\hline Ln (Revisions) & $\begin{array}{c}-0.090 * * * \\
(-6.382)\end{array}$ & $\begin{array}{c}-0.010 \\
(-0.767)\end{array}$ & $\begin{array}{c}0.021 * * * \\
(2.667)\end{array}$ & $\begin{array}{c}-0.059 * * * \\
(-2.978)\end{array}$ & $\begin{array}{c}0.047 \\
(1.301)\end{array}$ & $\begin{array}{l}0.025 * \\
(1.726)\end{array}$ \\
\hline Meet Expectations & $\begin{array}{c}0.078 * * * \\
(7.295)\end{array}$ & $\begin{array}{c}-0.010 \\
(-1.038)\end{array}$ & $\begin{array}{c}0.001 \\
(0.089)\end{array}$ & $\begin{array}{c}0.058 * * * \\
(3.898)\end{array}$ & $\begin{array}{c}-0.016 \\
(-0.594)\end{array}$ & $\begin{array}{c}0.001 \\
(0.080)\end{array}$ \\
\hline Negative Earnings & $\begin{array}{c}-0.024 \\
(-1.415)\end{array}$ & $\begin{array}{c}0.004 \\
(0.221)\end{array}$ & $\begin{array}{c}-0.010 \\
(-1.088)\end{array}$ & $\begin{array}{c}0.030 \\
(1.271)\end{array}$ & $\begin{array}{c}-0.030 \\
(-0.673)\end{array}$ & $\begin{array}{c}-0.028 \\
(-1.538)\end{array}$ \\
\hline Afternoon & $-0.041 *$ & 0.028 & $\begin{array}{r}0.007 \\
50\end{array}$ & $-0.088 * * *$ & 0.084 & -0.004 \\
\hline
\end{tabular}




\begin{tabular}{|c|c|c|c|c|c|c|}
\hline & $(-1.778)$ & $(1.243)$ & $(0.586)$ & $(-2.798)$ & (1.473) & $(-0.197)$ \\
\hline \multirow[t]{2}{*}{ Accruals } & -0.115 & 0.091 & $0.100 * *$ & 0.037 & $0.382 *$ & 0.150 \\
\hline & $(-1.518)$ & $(1.316)$ & $(2.490)$ & $(0.294)$ & (1.682) & $(1.563)$ \\
\hline \multirow[t]{2}{*}{ Momentum } & $0.073 * * *$ & -0.014 & $0.009 *$ & $0.048 * * *$ & 0.020 & -0.003 \\
\hline & $(6.716)$ & $(-1.351)$ & $(1.762)$ & $(3.371)$ & $(0.712)$ & $(-0.287)$ \\
\hline Constant & $\begin{array}{c}0.186 \\
(1.530)\end{array}$ & $\begin{array}{c}0.698 * * * * \\
(5.673)\end{array}$ & $\begin{array}{c}1.245 * * * \\
(20.493)\end{array}$ & $\begin{array}{l}-0.096 \\
(-0.525)\end{array}$ & $\begin{array}{c}2.363^{* * * * *} \\
(7.026)\end{array}$ & $\begin{array}{l}1.480 * * * \\
(14.313)\end{array}$ \\
\hline Firm FE & YES & YES & YES & YES & YES & YES \\
\hline Quarter FE & YES & YES & YES & YES & YES & YES \\
\hline Observations & 41,171 & 41,172 & 41,171 & 36,005 & 36,013 & 36,005 \\
\hline Adjusted $\mathrm{R}^{2}$ & 0.323 & 0.369 & 0.277 & 0.128 & 0.202 & 0.119 \\
\hline
\end{tabular}


Table 10

\section{Financial Expertise of CEO and Weather-Induced Behavioral Change}

This table shows multiple regression results for the influence of financial expertise on weather-induced behavioral change during earnings conference calls. We use the financial expertise classifications similar to Custodio and Metzger (2014): CEO who has previous experience in a finance related role or has working experience in large auditing firms. For columns (1) and (2), we focus on the net tone in Q\&A section from CEO. We focus on percentage of numbers usage in Q\&A section from CEO in column (3) and (4). At last two column, we switch our focus to the uncertainty words usage. Standard errors are clustered by firm and t-statistics are shown in parentheses. Detailed definitions for each variable are provided in Appendix I. Significance level: *** $\mathrm{p}<0: 01, * * \mathrm{p}<0: 05, * \mathrm{p}<0: 1$.

\begin{tabular}{|c|c|c|c|c|c|c|}
\hline \multirow{4}{*}{ Dependent Variable } & \multicolumn{6}{|c|}{ Financial Expert CEO } \\
\hline & \multicolumn{2}{|c|}{ Net Tone in Q\&A } & \multicolumn{2}{|c|}{$\%$ Numbers in Q\&A } & \multicolumn{2}{|c|}{ \% Uncertainty in Q\&A } \\
\hline & (1) & (2) & (3) & (4) & (5) & (6) \\
\hline & NO & YES & $\mathrm{NO}$ & YES & $\mathrm{NO}$ & YES \\
\hline \multirow[t]{2}{*}{ Bad Weather } & -0.012 & -0.029 & $-0.031 * * *$ & 0.021 & $0.017 * * *$ & -0.003 \\
\hline & $(-1.480)$ & $(-1.387)$ & $(-3.983)$ & $(0.963)$ & $(3.579)$ & $(-0.227)$ \\
\hline \multirow[t]{2}{*}{ CFO Attend } & $0.103 * * *$ & 0.063 & $-0.037 *$ & $-0.125 * *$ & $-0.021 * *$ & -0.005 \\
\hline & $(5.297)$ & $(1.267)$ & $(-1.854)$ & $(-2.306)$ & $(-2.223)$ & $(-0.177)$ \\
\hline \multirow[t]{2}{*}{ Ln(Size) } & $0.101 * * *$ & $0.128 * * *$ & $0.094 * * *$ & $0.103^{*}$ & $-0.057 * * *$ & $-0.052 * *$ \\
\hline & $(5.579)$ & $(2.771)$ & $(5.317)$ & $(1.834)$ & $(-6.142)$ & $(-2.353)$ \\
\hline \multirow[t]{2}{*}{ Book to Market } & $-0.094 * * *$ & $-0.167 * * *$ & $-0.119 * * *$ & $-0.149 * * *$ & $0.046 * * *$ & $0.065^{* *}$ \\
\hline & $(-4.178)$ & $(-2.770)$ & $(-4.978)$ & $(-2.741)$ & $(3.928)$ & $(2.105)$ \\
\hline \multirow[t]{2}{*}{ Return on Assets } & 0.184 & $1.481 *$ & -0.106 & 0.082 & 0.087 & -0.062 \\
\hline & $(1.036)$ & $(1.835)$ & $(-0.607)$ & $(0.124)$ & $(0.837)$ & $(-0.145)$ \\
\hline \multirow[t]{2}{*}{ Surprise Earnings } & $0.008 * * *$ & $0.009 * *$ & -0.001 & 0.000 & -0.001 & 0.002 \\
\hline & $(4.602)$ & (1.987) & $(-0.742)$ & $(0.043)$ & $(-1.378)$ & $(0.622)$ \\
\hline \multirow[t]{2}{*}{ Ln(Analysts) } & $-0.094 * * *$ & -0.013 & 0.025 & 0.033 & $0.021 * *$ & 0.034 \\
\hline & $(-5.606)$ & $(-0.243)$ & $(1.515)$ & $(0.722)$ & $(2.380)$ & (1.109) \\
\hline \multirow[t]{2}{*}{ Ln(Revisions) } & $-0.090 * * *$ & $-0.099 * *$ & -0.008 & -0.013 & $0.019 * *$ & 0.040 \\
\hline & $(-5.970)$ & $(-2.267)$ & $(-0.555)$ & $(-0.302)$ & $(2.425)$ & $(1.372)$ \\
\hline
\end{tabular}




\begin{tabular}{|c|c|c|c|c|c|c|}
\hline Meet Expectations & $\begin{array}{c}0.074 * * * \\
(6.446)\end{array}$ & $\begin{array}{c}0.110 * * * \\
(3.537)\end{array}$ & $\begin{array}{l}-0.020 * \\
(-1.952)\end{array}$ & $\begin{array}{c}0.068 * * \\
(2.394)\end{array}$ & $\begin{array}{c}-0.000 \\
(-0.004)\end{array}$ & $\begin{array}{c}-0.003 \\
(-0.158)\end{array}$ \\
\hline Negative Earnings & $\begin{array}{c}-0.035^{* *} * \\
(-1.982)\end{array}$ & $\begin{array}{c}0.039 \\
(0.650)\end{array}$ & $\begin{array}{c}0.002 \\
(0.091)\end{array}$ & $\begin{array}{c}0.028 \\
(0.540)\end{array}$ & $\begin{array}{c}-0.012 \\
(-1.261)\end{array}$ & $\begin{array}{c}0.032 \\
(1.054)\end{array}$ \\
\hline Afternoon & $\begin{array}{c}-0.035 \\
(-1.430)\end{array}$ & $\begin{array}{c}0.012 \\
(0.175)\end{array}$ & $\begin{array}{c}0.004 \\
(0.186)\end{array}$ & $\begin{array}{c}0.161 * * \\
(2.069)\end{array}$ & $\begin{array}{c}0.010 \\
(0.783)\end{array}$ & $\begin{array}{c}0.001 \\
(0.019)\end{array}$ \\
\hline Accruals & $\begin{array}{c}-0.097 \\
(-1.265)\end{array}$ & $\begin{array}{c}-0.584 \\
(-1.300)\end{array}$ & $\begin{array}{c}0.084 \\
(1.187)\end{array}$ & $\begin{array}{c}0.006 \\
(0.014)\end{array}$ & $\begin{array}{c}0.082 * * \\
(2.020)\end{array}$ & $\begin{array}{c}0.398 \\
(1.543)\end{array}$ \\
\hline Momentum & $\begin{array}{c}0.072 * * * \\
(6.376)\end{array}$ & $\begin{array}{c}0.083 * * \\
(2.025)\end{array}$ & $\begin{array}{c}-0.012 \\
(-1.139)\end{array}$ & $\begin{array}{c}-0.036 \\
(-1.044)\end{array}$ & $\begin{array}{l}0.009 * \\
(1.669)\end{array}$ & $\begin{array}{c}0.015 \\
(0.826)\end{array}$ \\
\hline Firm FE & YES & YES & YES & YES & YES & YES \\
\hline Quarter FE & YES & YES & YES & YES & YES & YES \\
\hline Observations & 36,403 & 4,768 & 36,404 & 4,768 & 36,403 & 4,768 \\
\hline Adjusted $\mathrm{R}^{2}$ & 0.327 & 0.324 & 0.376 & 0.349 & 0.280 & 0.270 \\
\hline
\end{tabular}


Table 11

\section{Executive Characteristics on Weather-Induced Behavioral Change}

This table shows the influence of executive characteristics (age, tenure, and gender) on weather-induced behavioral change during earnings conference calls. For each characteristic, we divide our original sample into two subsamples according to the top quartile of each characteristic. For example, we define a long tenured executive as an executive whose tenure at the firm is above the top quartile (top 25\%). The table transforms our original call level data into individual executive level data. We use the coefficient difference test developed by Paternoster et al. (1998) in our "Diff" column. We also highlight significant differences between each pair of coefficients. Detailed definitions for each variable are provided in Appendix I. Significance level: $* * * p<0: 01, * * \mathrm{p}<0: 05, * \mathrm{p}<0: 1$.

Managers (CEOs and CFOs)

\begin{tabular}{|c|c|c|c|c|c|c|c|c|c|}
\hline \multicolumn{10}{|c|}{ Dependent Variable: Net Tone in Q\&A } \\
\hline & \multicolumn{2}{|c|}{ Tenure } & \multicolumn{3}{|c|}{ Gender } & \multicolumn{4}{|c|}{ Age } \\
\hline & Short & Long & Diff & Male & Female & Diff & Young & Old & Diff \\
\hline \multirow[t]{2}{*}{ Bad Weather } & 0.004 & $-0.039 *$ & $0.043 * * *$ & -0.013 & 0.035 & $-0.048 *$ & 0.005 & $-0.027 *$ & 0.032* \\
\hline & $(0.390)$ & $(-2.990)$ & $(2.591)$ & $(-1.594)$ & $(1.304)$ & $(-1.711)$ & $(0.525$ & $(-1.815)$ & (1.812) \\
\hline Controls \& FEs & YES & YES & & YES & YES & & YES & YES & \\
\hline $\mathrm{N}$ & 28,216 & 15,299 & & 40,750 & 2,765 & & 32,231 & 11,232 & \\
\hline Adjusted $\mathrm{R}^{2}$ & 0.335 & 0.434 & & 0.319 & 0.577 & & 0.349 & 0.460 & \\
\hline \multicolumn{10}{|c|}{ Dependent Variable: \% Uncertainty in Q\&A } \\
\hline & \multicolumn{2}{|c|}{$\underline{\text { Tenure }}$} & & \multicolumn{2}{|c|}{ Gender } & & \multicolumn{2}{|c|}{$\underline{\text { Age }}$} & \\
\hline & Short & Long & Diff & Male & Female & Diff & Young & Old & Diff \\
\hline \multirow[t]{2}{*}{ Bad Weather } & 0.005 & $0.012^{*}$ & -0.007 & $0.010 * * *$ & $-0.030 * *$ & $0.040 * * *$ & 0.005 & 0.005 & 0.000 \\
\hline & $(1.122)$ & $(2.263)$ & $(-1.011)$ & $(2.707)$ & $(-2.100)$ & $(2.71)$ & $(1.103)$ & $(0.754)$ & $(0.000)$ \\
\hline Controls \& FEs & YES & YES & & YES & YES & & YES & YES & \\
\hline $\mathrm{N}$ & 28,216 & 15,299 & & 32,231 & 11,232 & & 40,750 & 2,765 & \\
\hline Adjusted $\mathrm{R}^{2}$ & 0.326 & 0.387 & & 0.338 & 0.431 & & 0.307 & 0.442 & \\
\hline
\end{tabular}




\section{Table 12}

\section{Weather and Post-Earnings Announcement Drift}

This table shows multiple regression results for weather conditions and post-earnings announcement drift (PEAD). We calculate PEAD as the cumulative abnormal return over three different timeframes.

Variables Afternoon, Meet Expectation, Return on Asset and Ln (Analysts) are insignificant and included in additional controls. Standard errors are clustered by firm and t-statistics are shown in parentheses. Detailed definitions for each variable is provided in Appendix I. Significance level: *** $p<0: 01, * * p<$ $0: 05, * \mathrm{p}<0: 1$

\begin{tabular}{|c|c|c|c|}
\hline VARIABLES & $\begin{array}{c}(1) \\
\text { PEAD }[2,30]\end{array}$ & $\begin{array}{c}(2) \\
\text { PEAD }[2,45]\end{array}$ & $\begin{array}{c}(3) \\
\text { PEAD }[2,60]\end{array}$ \\
\hline Surprise Earnings & $\begin{array}{c}0.082 * * * \\
(3.197)\end{array}$ & $\begin{array}{c}0.101 * * * \\
(3.046)\end{array}$ & $\begin{array}{c}0.090 * * \\
(2.264)\end{array}$ \\
\hline Bad Weather & $\begin{array}{c}-0.544 * * * \\
(-5.102)\end{array}$ & $\begin{array}{c}-0.785 * * * \\
(-5.780)\end{array}$ & $\begin{array}{c}-0.859 * * * \\
(-5.313)\end{array}$ \\
\hline Surprise Earnings*Bad Weather & $\begin{array}{c}-0.070 * * \\
(-2.161)\end{array}$ & $\begin{array}{c}-0.115 * * * \\
(-2.766)\end{array}$ & $\begin{array}{c}-0.137 * * * \\
(-2.696)\end{array}$ \\
\hline Net Tone & $\begin{array}{c}0.516^{* * * *} \\
(5.465)\end{array}$ & $\begin{array}{c}0.650 * * * \\
(5.250)\end{array}$ & $\begin{array}{c}0.809 * * * \\
(5.394)\end{array}$ \\
\hline$\%$ Numbers & $\begin{array}{c}0.153 \\
(1.554)\end{array}$ & $\begin{array}{c}0.334 * * * \\
(2.699)\end{array}$ & $\begin{array}{c}0.535 * * * \\
(3.627)\end{array}$ \\
\hline Ln (Size) & $\begin{array}{c}-0.480 * * * \\
(-3.045)\end{array}$ & $\begin{array}{c}-1.353 * * * \\
(-6.618)\end{array}$ & $\begin{array}{c}-2.121 * * * \\
(-8.241)\end{array}$ \\
\hline Book to Market & $\begin{array}{c}4.123 * * * \\
(14.633)\end{array}$ & $\begin{array}{l}6.101 * * * \\
(16.878)\end{array}$ & $\begin{array}{l}7.826 * * * \\
(17.214)\end{array}$ \\
\hline Ln (Reversion) & $\begin{array}{l}-0.317 * \\
(-1.723)\end{array}$ & $\begin{array}{c}-0.199 \\
(-0.843)\end{array}$ & $\begin{array}{c}-0.320 \\
(-1.114)\end{array}$ \\
\hline Negative Earning & $\begin{array}{c}-0.386 \\
(-1.458)\end{array}$ & $\begin{array}{c}-0.379 \\
(-1.126)\end{array}$ & $\begin{array}{l}-0.654^{*} \\
(-1.653)\end{array}$ \\
\hline Accrual & $\begin{array}{c}-1.242 \\
(-0.869)\end{array}$ & $\begin{array}{c}-4.159 * * \\
(-2.349)\end{array}$ & $\begin{array}{c}-8.803 * * * \\
(-4.135)\end{array}$ \\
\hline Momentum & $\begin{array}{c}-7.509 * * * \\
(-47.065)\end{array}$ & $\begin{array}{c}-10.918 * * * \\
(-53.679)\end{array}$ & $\begin{array}{c}-14.301 * * * \\
(-57.786)\end{array}$ \\
\hline Constant & $\begin{array}{l}2.225^{*} \\
(1.870)\end{array}$ & $\begin{array}{c}7.728 * * * \\
(5.020)\end{array}$ & $\begin{array}{c}13.092 * * * \\
(6.889)\end{array}$ \\
\hline Additional Controls & YES & YES & YES \\
\hline Firm FE & YES & YES & YES \\
\hline Quarter FE & YES & YES & YES \\
\hline Observations & 57,153 & 57,155 & 57,155 \\
\hline Adjusted R-squared & 0.107 & 0.134 & 0.155 \\
\hline
\end{tabular}




\section{Figure 1}

\section{Comparison Between Miami and Seattle}

This figure shows deseasonalized cloud cover comparison between Miami and Seattle to demonstrate the validity of the weather measurement that we construct. The first row shows histogram comparisons between these two cities and corresponding states. The second and third rows present the corresponding statistics for each histogram.

City Comparison

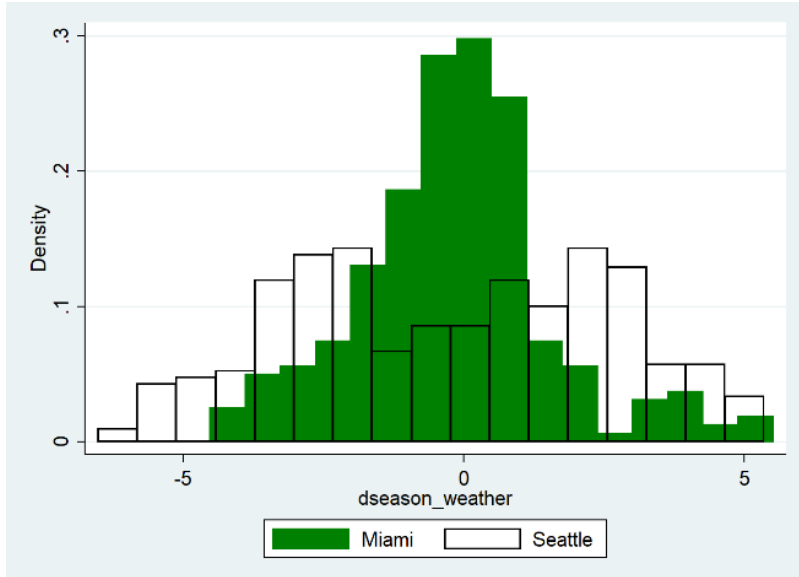

$\underline{\text { State Comparison }}$

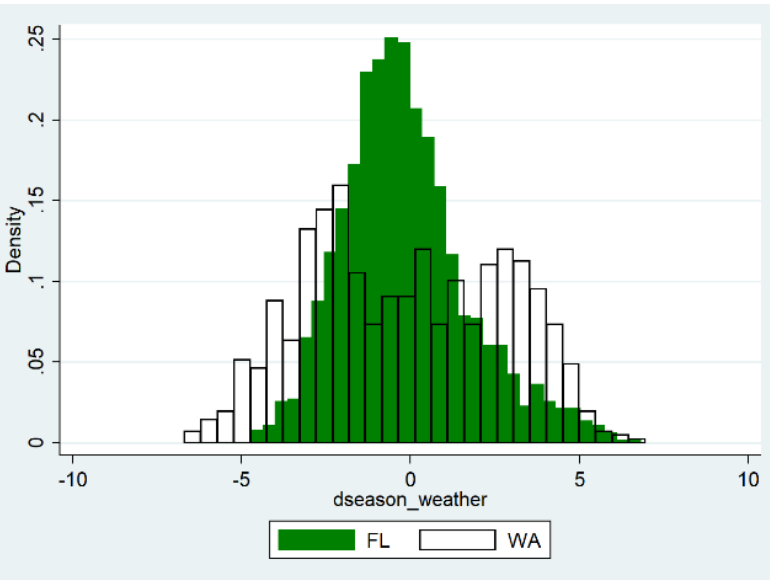

\section{City Comparison}

Miami

\begin{tabular}{llllllll}
$\mathrm{N}$ & Mean & Std Dev & $\mathrm{N}$ & Mean & Std Dev & Difference & T-statistic \\
394 & -0.145 & 1.670 & 497 & -0.376 & 2.726 & 0.231 & 1.477 \\
\hline
\end{tabular}

\begin{tabular}{|c|c|c|c|c|c|c|c|}
\hline \multirow{2}{*}{\multicolumn{8}{|c|}{ State Comparison }} \\
\hline & & & & & & & \\
\hline $\mathrm{N}$ & Mean & Std Dev & $\mathrm{N}$ & Mean & Std Dev & Difference & T-statistic \\
\hline 2826 & -0.187 & 1.832 & 1387 & -0.213 & 2.768 & 0.026 & 0.320 \\
\hline
\end{tabular}




\section{Appendix I}

\section{Variable Definitions}

\begin{tabular}{|c|c|}
\hline Variable & Definition \\
\hline Accruals & $\begin{array}{l}\text { Quarterly accruals over total assets. Accruals are defined as IBCY- } \\
\text { OANCFY using quarterly Compustat data }\end{array}$ \\
\hline Afternoon & $\begin{array}{l}\text { An indicator variable to distinguish between morning earnings } \\
\text { conference call and afternoon earnings conference call }\end{array}$ \\
\hline Bad Weather & $\begin{array}{l}\text { An indicator variable equals one if the call date's seasonally adjusted } \\
\text { cloud cover is larger than the median deseasonalized cloud cover in the } \\
\text { whole sample }\end{array}$ \\
\hline Book to Market & Book equity over market equity \\
\hline CAR $[-1,1]$ & $\begin{array}{l}\text { Cumulative Abnormal Return from }-1 \text { days to }+1 \text { days around earnings } \\
\text { conference call date }\end{array}$ \\
\hline CEO Attend & $\begin{array}{l}\text { An indicator variable equals one if CEO appears in the earnings } \\
\text { conference call }\end{array}$ \\
\hline CFO Attend & $\begin{array}{l}\text { An indicator variable equals one if CFO appears in the earnings } \\
\text { conference call }\end{array}$ \\
\hline Dcloud Cover & $\begin{array}{l}\text { Call date's cloud cover minus the average cloud cover in the same } \\
\text { week of the year during the whole sample period }\end{array}$ \\
\hline Dcloud Cover in NYC & Call date's deseasonalized cloud cover in New York City \\
\hline Large Firm & $\begin{array}{l}\text { A dummy variable equals one if the firm size is larger than the median } \\
\text { firm size in the whole sample }\end{array}$ \\
\hline Ln(Analysts) & $\begin{array}{l}\text { Natural log of the number of analysts follows the firm during the } \\
\text { quarter for the company }\end{array}$ \\
\hline Ln(Revisions) & $\begin{array}{l}\text { Natural log of the number of earnings estimate revisions by an analyst } \\
\text { during the quarter for the company }\end{array}$ \\
\hline $\operatorname{Ln}($ Size $)$ & Natural log of the firm's total asset \\
\hline Major State & $\begin{array}{l}\text { A dummy variable equals one if the firm is in one of the following } \\
\text { states: NY, CA, and TX }\end{array}$ \\
\hline Meet Expectations & $\begin{array}{l}\text { A dummy variable equals one if the firm meets analyst expectation in } \\
\text { that quarter }\end{array}$ \\
\hline Momentum & Measured by lag cumulative 12 -month returns. \\
\hline Negative Earnings & $\begin{array}{l}\text { A dummy variable equals one if the firm has negative earning in that } \\
\text { quarter }\end{array}$ \\
\hline Net Tone from CEO & $\begin{array}{l}\text { The difference between the number of positive words and negative } \\
\text { words said by CEO in Q\&A section, scaled by the total number of } \\
\text { words said by CEO in Q\&A section. }\end{array}$ \\
\hline Net Tone from CFO & $\begin{array}{l}\text { The difference between the number of positive words and negative } \\
\text { words said by CFO in Q\&A section, scaled by the total number of } \\
\text { words said by CFO in Q\&A section. }\end{array}$ \\
\hline Net Tone in Q\&A & $\begin{array}{l}\text { The difference between the number of positive words and negative } \\
\text { words said by all executives in Q\&A session, scaled by the total } \\
\text { number of words said by all executives in Q\&A session. }\end{array}$ \\
\hline PEAD $[a, b]$ & $\begin{array}{l}\text { Post-earnings announcement drift as the accumulative abnormal return } \\
\text { between day a and day b after the earnings conference call }\end{array}$ \\
\hline Return on Assets & Net income over assets \\
\hline Surprise Earnings & $\begin{array}{l}\text { The difference between actual earnings and analysts' forecast divided } \\
\text { by the standard deviation of analyst forecast }\end{array}$ \\
\hline
\end{tabular}




\begin{tabular}{|c|c|}
\hline Total Negative Words & Total negative words in the earnings transcripts \\
\hline Total Positive Words & Total positive words in the earnings transcripts \\
\hline Total Words & Total words in the earnings transcripts \\
\hline Total Words in Pre & Total words in presentation section of the earnings transcripts \\
\hline Total Words in Q\&A & Total words in Q\&A section of the earnings transcripts \\
\hline$\%$ Numbers from CEO & $\begin{array}{l}\text { Total number of numeric phrases said by CEO in Q\&A section, over } \\
\text { the sum of the count of words and numbers said by CEO in Q\&A } \\
\text { section. }\end{array}$ \\
\hline$\%$ Numbers from $\mathrm{CFO}$ & $\begin{array}{l}\text { Total number of numeric phrases said by CFO in Q\&A section, over } \\
\text { the sum of the count of words and numbers said by CFO in Q\&A } \\
\text { section. }\end{array}$ \\
\hline$\%$ Numbers in Q\&A & $\begin{array}{l}\text { Total number of numeric phrases spoken by managers in Q\&A, over } \\
\text { the sum of the count of words and numbers in Q\&A. }\end{array}$ \\
\hline$\%$ Uncertainty in Q\&A & $\begin{array}{l}\text { Total number of uncertainty words spoken by managers in Q\&A, over } \\
\text { the sum of the count of words in Q\&A }\end{array}$ \\
\hline$\%$ Uncertainty from CEO & $\begin{array}{l}\text { Total number of uncertainty words said by CEO in Q\&A section, over } \\
\text { the sum of the count of words and numbers said by CEO in Q\&A } \\
\text { section. }\end{array}$ \\
\hline$\%$ Uncertainty from $\mathrm{CFO}$ & $\begin{array}{l}\text { Total number of uncertainty words said by CFO in Q\&A section, over } \\
\text { the sum of the count of words and numbers said by CFO in Q\&A } \\
\text { section. }\end{array}$ \\
\hline
\end{tabular}

